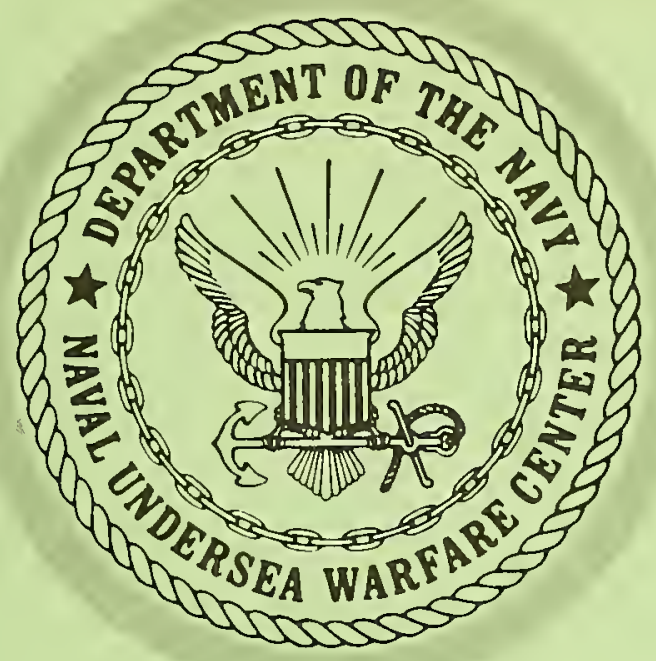

\title{
ПUW C
}

\section{NUWC TEMPERATURE CALIBRATION FACILITY}

RECENT IMPROVEMENTS AND INTERORGANIZATIONAL CROSS-CALIBRATION RESULTS

By C. D. Curtis

Ocean Sciences Department

San Diego, California

8 February 1968

$Q C$
271.8
.63
19
1968

DISTRIBUTION STATEMENT

S DOCUMENT HAS BEEN APPROVED FOR PUBLIC RELEASE AND SALE; ITS DISTRIBUTION IS UNLIMITED. 


\section{NAVAL UNDERSEA WARFARE CENTER An activity of the Naval Material Command}

G. H. Lowe, Capt., USN

Cammander

Wm. B. McLean, Ph.D.

Technical Directar

The work was done under SR 10403 01, Task 0580 (NEL L 40471)。 This report covers work from October 1958 to March 1967 and was approved for publication $8 \mathrm{Feb}-$ ruary 1968. The author wishes to acknowledge the help of $J . R$. Olson and P. G. Hansen in the selection of electronic equipment, and of W. C. McSparron, P. E. Parnell, and M. W. Cooke in mechanical design and construction.

Released by

E. C. LaFond, Head Marine Environment

Division
Under authority of

G. H. Curl, Head

Ocean Sciences Department

The distribution control point for this report is NUWC, San Diego, California. 


\section{THE PROBLEM}

Develop a controlled-temperature tank and pressure system for calibrating deep-sea reversing thermometers and other precise temperature-measuring instruments. This report covers improvements made to the system during the last 10 years.

\section{RESULTS}

1. Improvements made to the Naval Undersea Warfare Center Temperature Calibration Facility have enabled it to furnish vital support to oceanographic research groups.

2. The improvements have made possible the acquisition of more accurate data and the testing of more varied types of temperature sensors.

\section{RECOMMENDATIONS}

1. Utilize the facility for precise temperature calibrations and for studies that require constant temperature.

2. Continue development directed toward improving the mechanical, electrical, and electronic components of the facility. 



\section{CONTENTS}

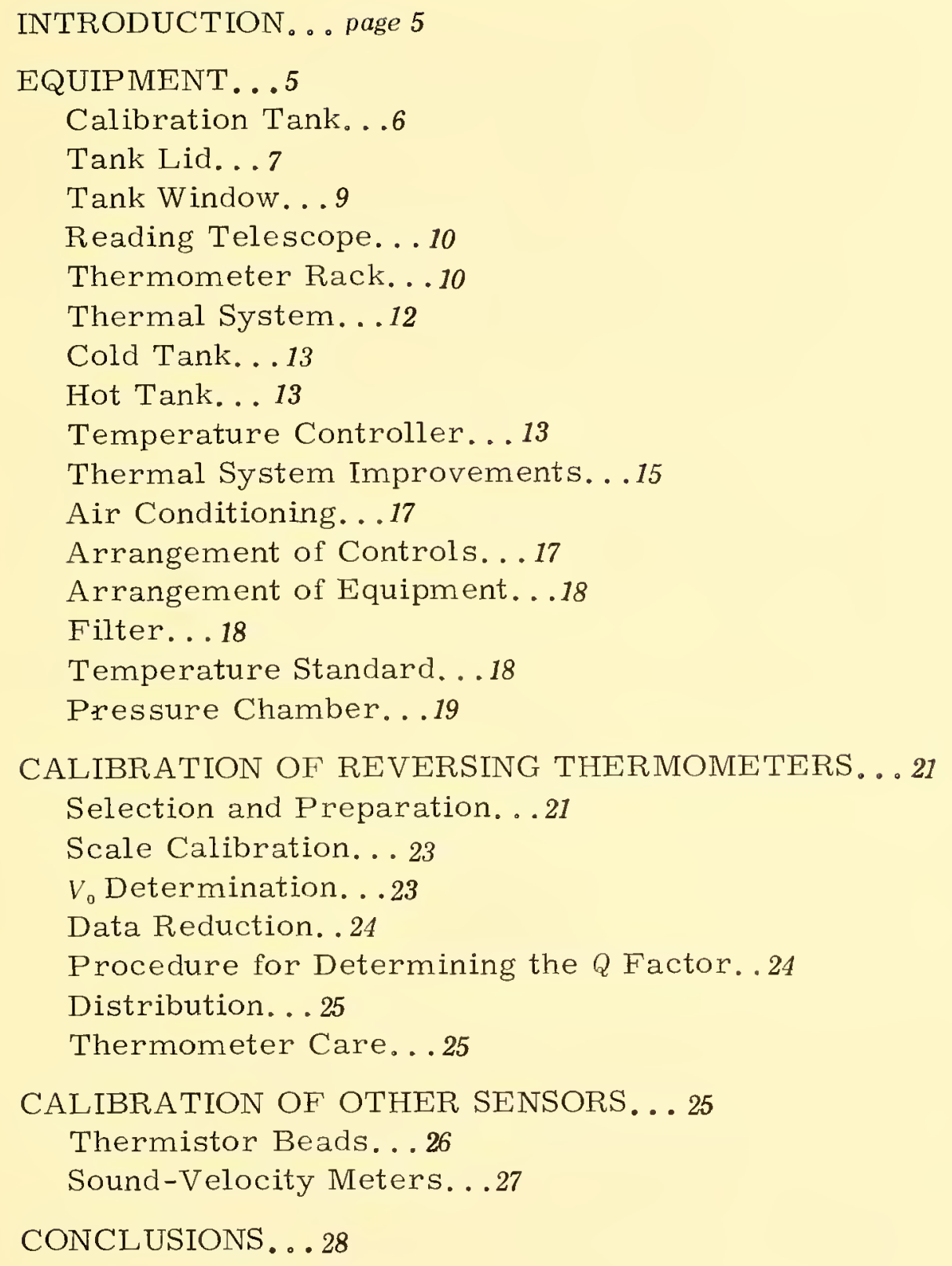

RECOMMENDATIONS . . 28

APPENDIX: RESULTS OF CROSS-CALIBRATION

PROGRAM. . . 29 


\section{ILLUSTRATIONS}

1 Calibration tank with control panel... page 6

2 Calibration tank lid (view from left side)...7

3 Viewing window and telescope unit... 9

4a Rack for holding 24 reversing thermometers and including stirring propellers at diagonal corners... 11

4b Platinum resistance thermometer and quartz temperature probe...11

5 Auxiliary thermal system (hot and cold tanks)... 12

6 Temperature controller with Mueller bridge and null detector. . 14

7 Schematic of circulating system... 16

8 Access to all controls by operator. . 17

9 Pressure vessel for calibration of unprotected reversing thermometers. . . 20

10 Deadweight pressure gage with hand pump and valving system... 20

11 Exercising and storage rack for reversing thermometers. . 21

12 Reversing thermometer calibration sheet... 22

13 Resistance bridge for calibrating thermistors. . . 26

\section{TABLES}

A 1 Thermometer grouping. . page 29

A2 Comparison of laboratories' facilities... 30

A 3 Cross-calibration tolerances to be used for future work. . 30

A4 Thermometer cross-calibration. . . 31-37

A5 Repeatability of reversing thermometer calibrations by NUWC...38

A6 Comparison of $V_{0}$ determinations by the four laboratories and the manufacturer... 39

A7 Q-factor cross-calibration comparison for six unprotected reversing thermometers... 40 


\section{INTRODUCTION}

The Naval Undersea Warfare Center (NUWC) Temperature Calibration Facility was originally designed for the calibration of deep-sea reversing thermometers. ${ }^{1}$ Since that time its function has been expanded to include the calibration of other oceanographic research instruments used in the measurement of temperature for Navy acoustic studies. For example, such devices as the sensing elements of the NUWC Thermistor Chain, ${ }^{2}$ which is now employed in large-scale acquisition of data on the temperature structure of the upper layers of the sea, are routinely calibrated in the tank.

This report describes the improvements made to the NUWC Temperature Calibration Facility during the last 10 years and provides a guide for the installation and use of such a facility in the support of an oceanographic program. It also presents the results of a deep-sea reversing thermometer cross-calibration program in which the facility was used (see Appendix).

\section{EQUIPMENT}

The present NUWC Temperature Calibration Facility represents the result of a continued effort toward improvement in reliability, accuracy, and accessibility. Its principal components are a main calibration tank (fig. 1); tank lid (fig. 2); reading telescope (figs. 1 and 3); thermal system (figs. 5 and 7); platinum thermometer and temperature-control unit (figs. $4 \mathrm{~b}$ and 6 ).

${ }^{1}$ Navy Electronics Laboratory Report 784, A Temperature-Controlled Tank for Calibrating Reversing Thermometers, by J. S. Black, 6 May 1957. ${ }^{2}$ Navy Electronics Laboratory Report 1395, Vertical and Horizontal Thermal Structures in the Sea, by E. C. LaFond and K. G. LaFond, 29 July 1966. 


\section{CALIBRATION TANK}

The main tank is rectangular. Its internal dimensions are 28 by 24 by 31 inches, and its capacity is 70 gallons. It is supported 2-1/2 feet above the floor by upright aluminum pipes mounted at its corners. It is insulated on all sides with cork, 4-1/2 inches thick, backed by sheets of waterproof plywood. The inner liner is constructed of Type 304 stainless steel, the front panel being $1 / 2$ inch thick and the bottom and other three sides being $3 / 32$ inch thick. The front panel supports the glass panes for two lighting ports and furnishes rigid backing for the centrally located viewing window which is clamped against it and sealed with an "O" ring. All edges are welded. The original liner, constructed of Lucite sheets glued at their edges, was discarded because it deteriorated in the presence of the 25-percent solution of ethyl alcohol (used to prevent freezing and to control growth of algae).

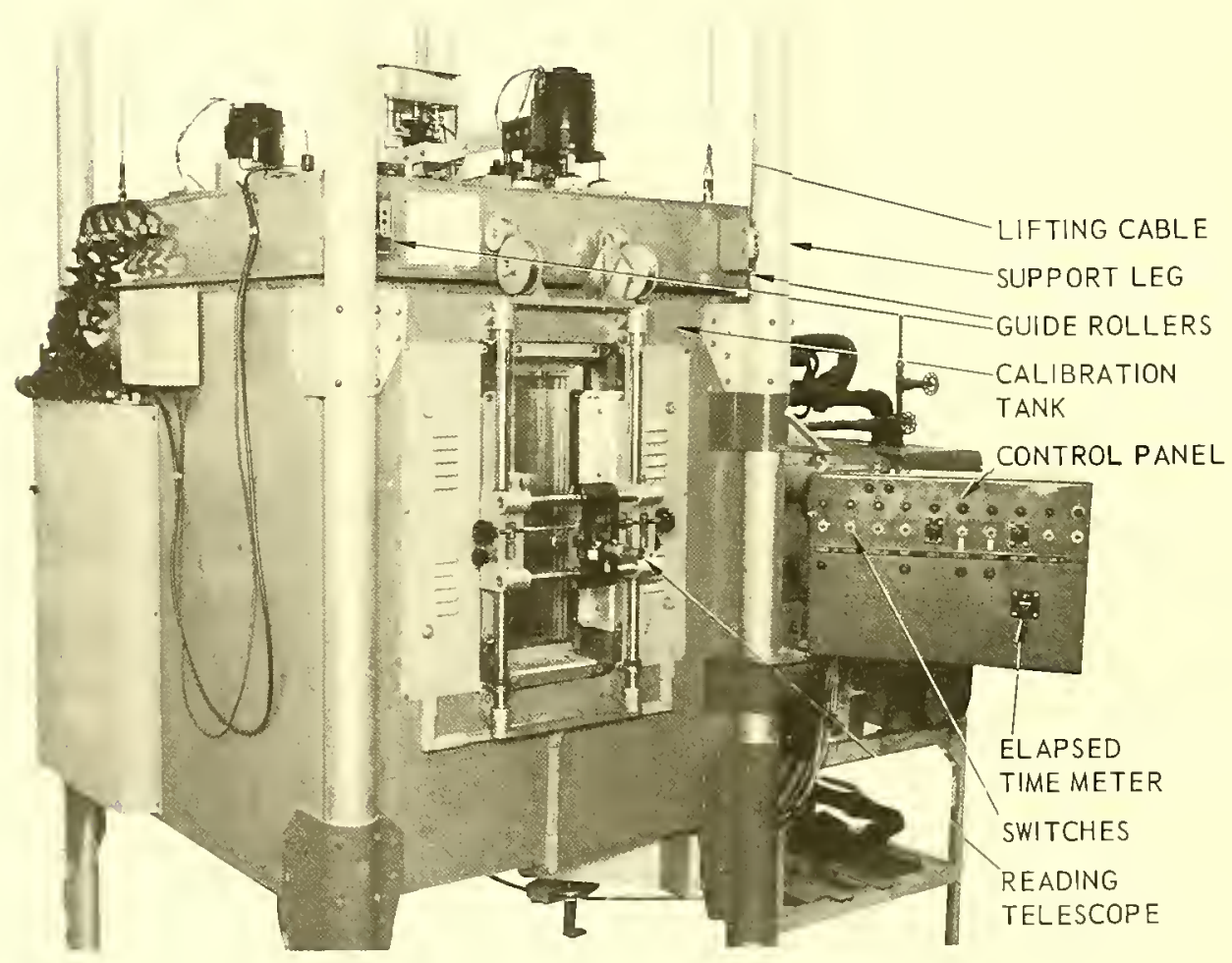

Figure 1. Calibration tank with control panel. 
Construction and insulation of the main tank lid (fig. 2) are similar to those of the main tank body. The frame and sheathing are of 3/4-inch marine plywood and wooden 2-by-4's, and the insulation consists of 4-1/2-inch corkboard. Guide rollers (fig. 1) keep the lid caged between the four aluminum pipe legs used to support the tank. The lid can be raised 30 inches by means of $5 / 32$-inch stainless-steel lifting cables attached to its corners. These cables pass over pulleys mounted at the top of the aluminum legs and go down through the legs to a point just below the bottom of the tank. Here the cables exit through holes and pass, via other pulleys, to a cable drum which is suspended from the bottom framework of the tank and

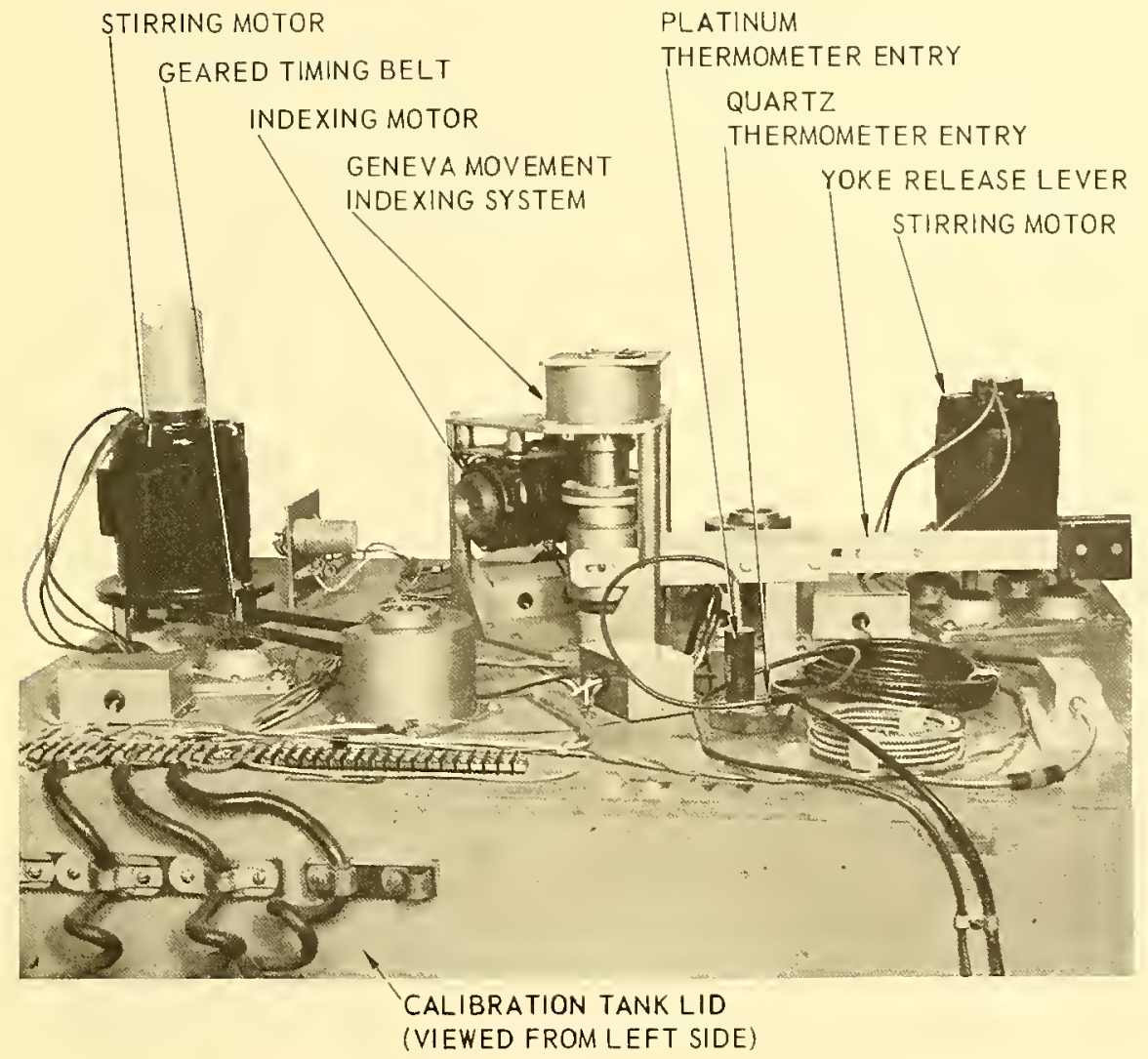

Figure 2. Calibration tank lid (view from left side). 
driven by an electric motor. A standard platinum resistance thermometer and a temperature sensing quartz probe penetrate an aperture in the lid (fig. 2). Another hole provides for the entry of electrical leads for connection to any electronic equipment being calibrated. A motor and accessory drive, situated on the right side, are used to rotate the thermometer rack through $180^{\circ}$ in a vertical plane while the lid is closed. Another motor, centrally located on top of the lid, drives a system of gears and cams (known as a Geneva movement) (fig. 2) which, alternately, advances and holds the rack stationary, to enable the thermometers to be read successively at the telescope. This is the indexing system. Indexing time between thermometers is 7 seconds.

Two shock-mounted 1/10-hp stirring motors, connected by rubber driving belts to two stirring shafts, are installed on the tank lid. The $\mathrm{V}$-belts formerly used to drive the stirring propellers were irregular in thickness and caused vibration which was transmitted through the lid to the thermometer rack, making the etchings and meniscus of the thermometers appear blurred. This problem was solved by substituting flat, geared, timing belts of uniform cross section throughout their length for the V-belts. A stainless-steel, four-bladed propeller is mounted on each stirring shaft at diagonal corners of the lid (fig. 4a, page 11). The thrust of one is up and of the other down, to impart a vertical rotary motion to the water for thorough mixing.

A problem was encountered when the Oilite bronze propeller-shaft bearings wore rapidly below the waterline. Nylatron, a graphite-impregnated Nylon, was tried as a bearing material but it swelled in water and seized the shafts. Teflon was also tried but it too caused seizure. In addition, the downward pull of the right-hand propeller plus the weight of its shaft caused the thrust face of the bearing to flake, and rapid wear occurred. This problem did not appear in the left-hand bearings because here thrust is down, offsetting the weight of the shaft. The problem was solved by using a composite bearing composed of Type 316 stainless-steel balls carried in a Nylon retainer and running in Delrin inner and outer races.*

*No. 21462-9 Type A, General Bearing Co., West Nyack, New York 


\section{TANK WINDOW}

The oceanographic instruments being calibrated are viewed through the tank window (fig. 3) which measures 9 by 19 inches and is made up of four panes of 1/4-inch glass, opaque to infrared. The three dead-air spaces between the panes make conductive heat transfer negligible, and the optically ground glass gives undistorted visibility. Originally a wooden frame supported the thermopane, but alternate drying and soaking caused variation of its dimensions and the seal developed a leak. A Micarta frame, impervious to water, was substituted and no leaks have developed in several years of use.

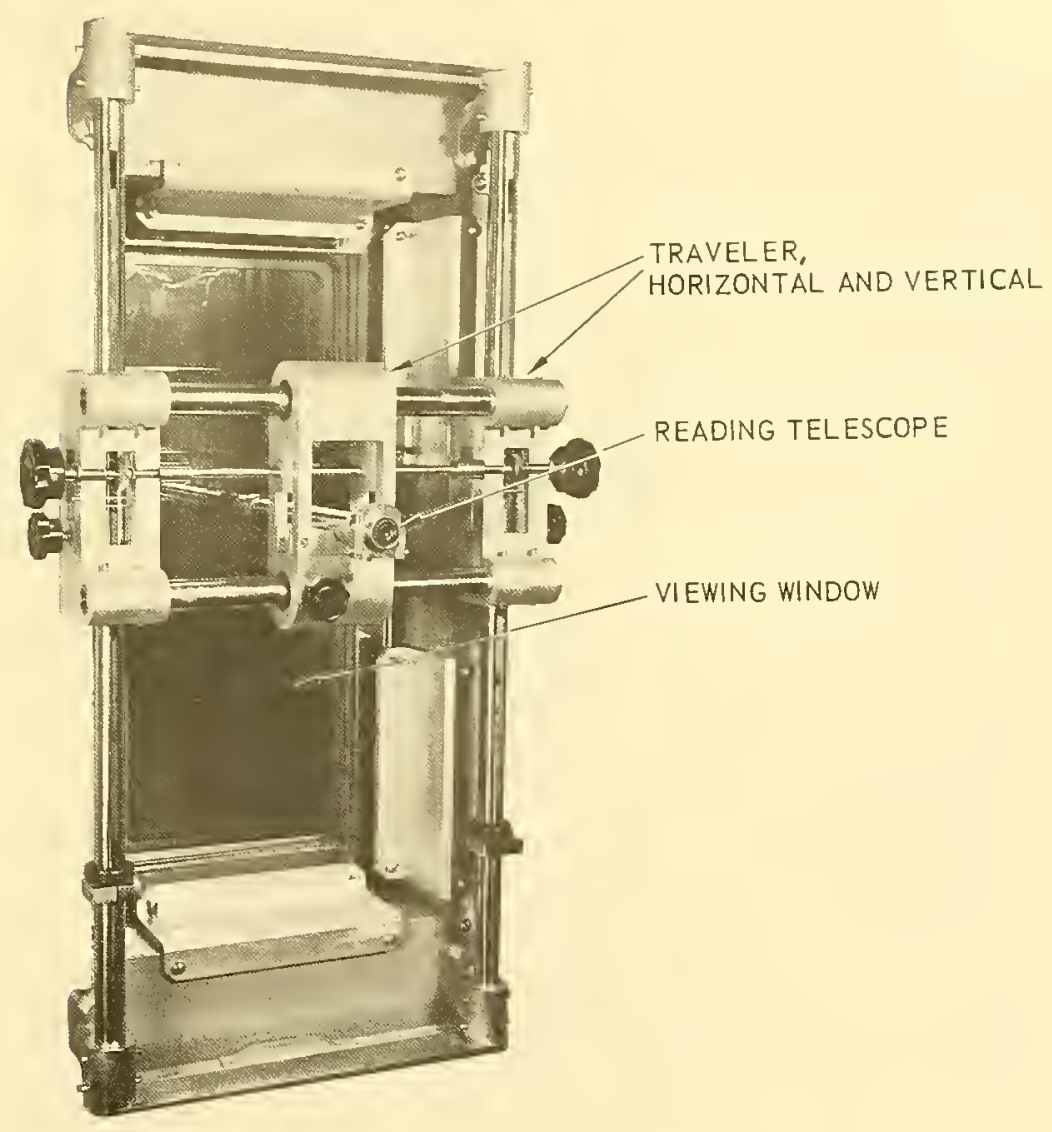

Figure 3. Viewing window ond telescope unit. 


\section{READING TELESCOPE}

The 20X erecting telescope (fig. 3) can focus to a minimum distance of 10 inches. At a 13 -inch distance its field is about $1 \mathrm{inch}$, and the main and auxiliary thermometers can be read without lateral adjustment. The assembly of telescope and traveler was aligned to make the telescope precisely perpendicular to the axis of the thermometers which eliminates error due to parallax.

\section{THERMOMETER RACK}

Two disks of 1/2-inch-thick Micarta, held 15 inches apart and rigidly fastened to a stainless-steel shaft passing through their centers, form the thermometer rack (fig. 4a). Spring-loaded, rubber-faced cups are positioned at the perimeter of one disk with matching rubber-faced screw-adjustable cups on the other. The assembly will hold 24 deep-sea reversing thermometers, and smaller holes are provided for supporting the same number of ordinary stem thermometers. Both ends of the shaft have a coupling designed to engage a slotted yoke on the lower end of a driveshaft coming through the lid from the Geneva movement. Power supplied by a $1 / 10-\mathrm{hp}$ reduction-gear indexing motor on the tank lid rotates the rack to bring each thermometer in front of the reading telescope.

In the original design, reversal of the thermometer rack was accomplished by throwing a "Reversing-Start" switch followed by a "Reversing" switch on the control panel. Problems were encountered in reversing. To overcome these problems, a solenoid-actuated locking plunger was installed to engage one of the notches of the detent wheel at the precise moment the motor current is cut off by the rack driving lug (fig. 4a). Because the microswitch and solenoid system which lifted the indexing yoke was exposed to the humid conditions present in the tank, its action was erratic with occasional mechanical binding and electrical failure. This assembly was removed and a simple, manually operated, yoke release lever (fig. 2) installed to perform the same function. Its retractable handle is just above the tank lid within easy reach of the operator. As a safety feature a 


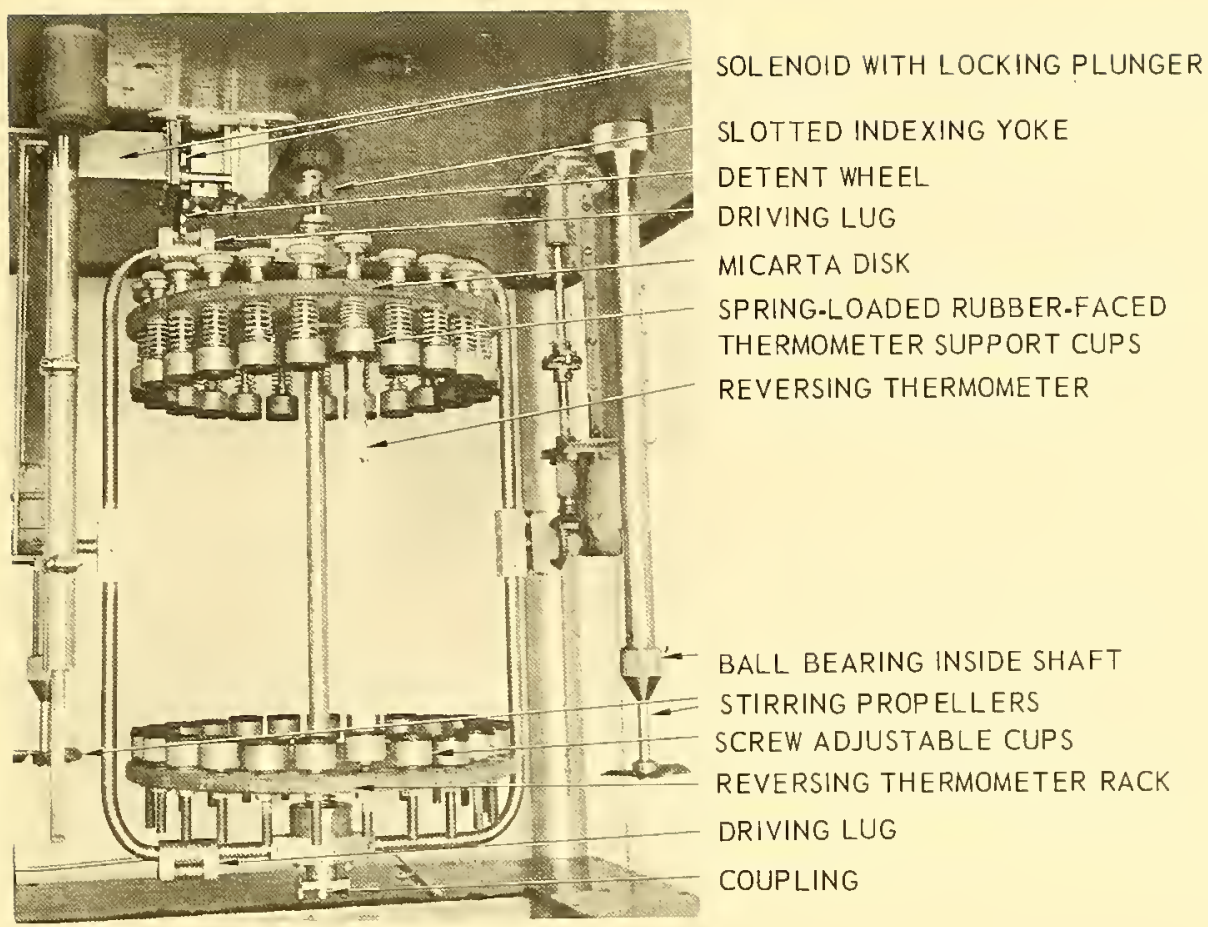

Figure 4a. Rack for holding 24 reversing thermometers and including stirring propellers at diagonal corners.

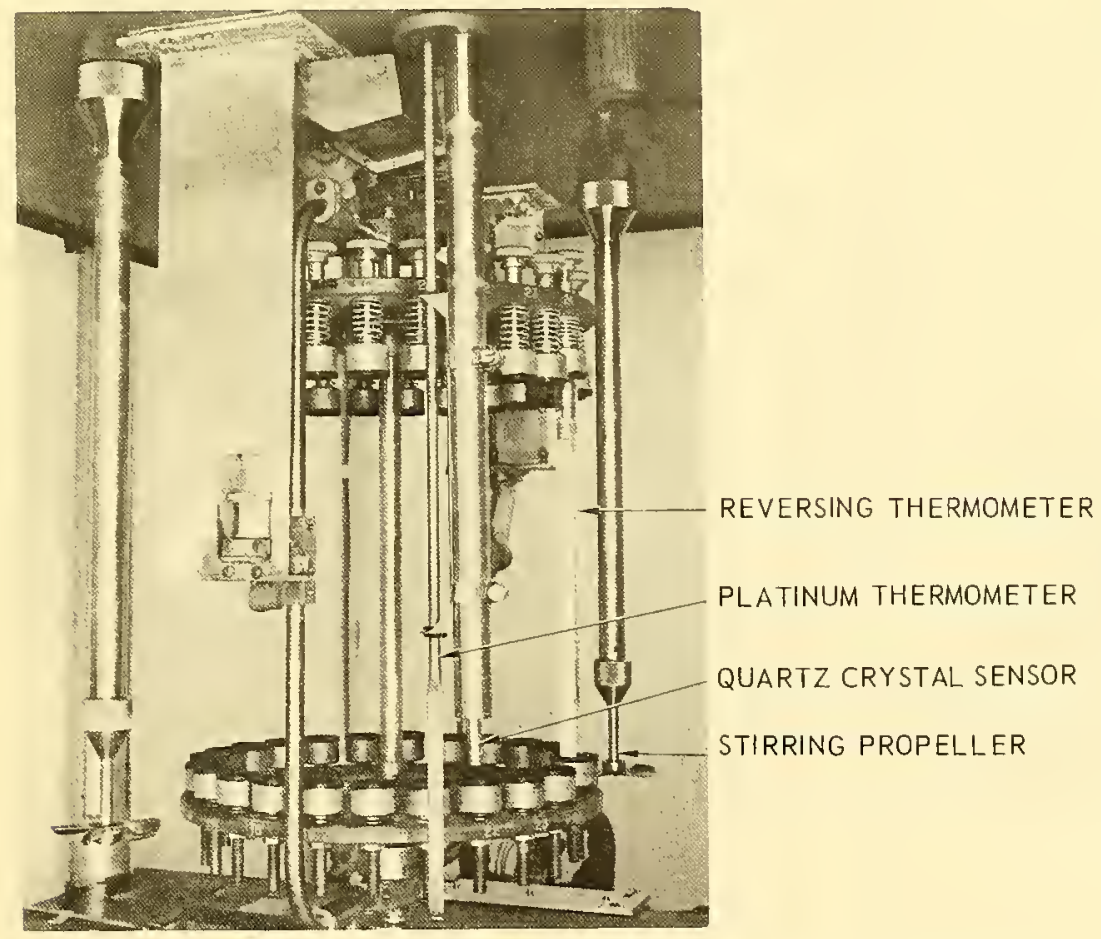

Figure 4b. Platinum resistance thermometer and quartz temperature probe. 
microswitch was mounted on the yoke lever, which allowed the reversing motor to be energized only when the indexing yoke was lifted clear of the rack.

\section{THERMAL SYSTEM}

To maintain the calibration tank at a constant temperature below ambient, an auxiliary thermal system (fig. 5) pumps refrigerated water into it in quantities sufficient to offset its natural rise in temperature toward that of the room. To maintain its temperature above ambient, the auxiliary system pumps heated water into it to cancel the effect of heat loss. The water injection is automatically regulated by solenoid valves which are controlled by a thermal sensor in the calibration tank.

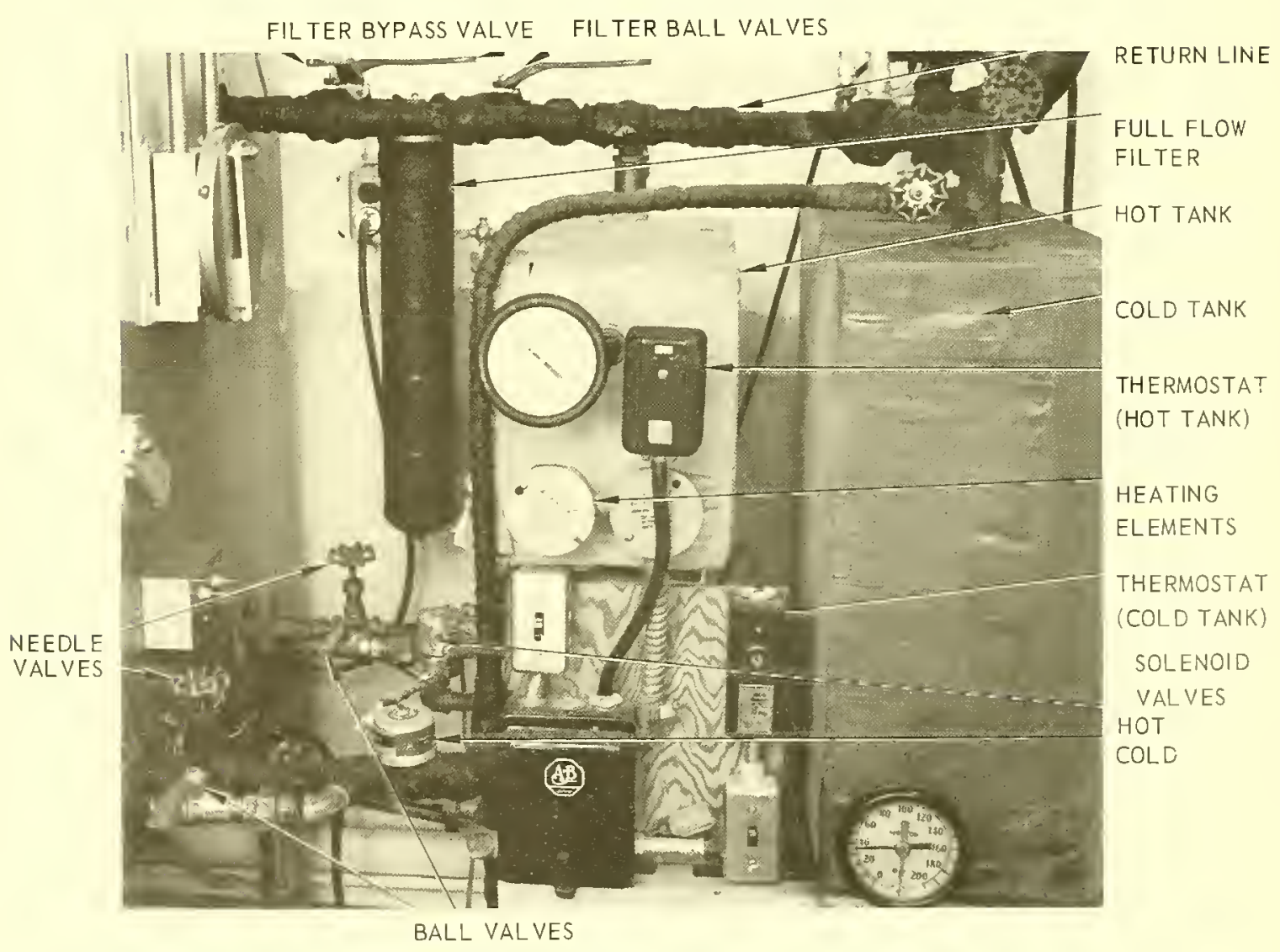

Figure 5. Auxiliary thermal system (hot and cold tanks). 
The refrigerated water supply is held in a $20-$ gallon tank insulated with a 1 -inch layer of cork. The dimensions of the cold tank, 28 by 9 by 22 inches, were determined by the size of the refrigeration coils mounted inside. The cold tank is situated next to the hot tank with which it shares a common return line from the main calibration tank. It is cooled by use of a compressor of sealed-unit construction mounted outside the building to provide proper air circulation as well as noise suppression. The compressor is rated at a 3 -ton capacity and replaces the original reciprocating-type unit which was unreliable and rated at only 1.2 tons. A manually adjustable thermostat (fig. 5) maintains the temperature of the contents of the cold tank to within $\pm 2{ }^{\circ} \mathrm{C}$ of any desired temperature between $-12^{\circ} \mathrm{C}$ and $+10^{\circ} \mathrm{C}$.

\section{HOT TANK}

The capacity of the hot tank is 10 gallons, and the tank is insulated all over with 1 -inch thick cork board. It is located between the cold tank and the calibration tank and is connected to the latter in a closed system, the water pumped out from the bottom being replaced at the top by a return line. A bourdon tube thermostat (hot tank) regulating two 2000-watt, 230-volt heating elements connected in series holds the temperature of the water to within $\pm 2^{\circ} \mathrm{C}$ of any desired value between $20^{\circ} \mathrm{C}$ and $90^{\circ} \mathrm{C}$. The temperature of the main tank rises about $5{ }^{\circ} \mathrm{C}$ when 10 gallons of water at $80^{\circ} \mathrm{C}$ is pumped rapidly into it.

\section{TEMPERATURE CONTROLLER}

A constant temperature is achieved in the calibration tank by the injection of hot or cold water to counteract any drift away from the desired temperature. Electrically controlled solenoid valves and manually adjustable needle valves (fig. 5) regulate timing and quantity 
of injection. The choice of hot or cold is made by the main tank temperature controller (fig. 6) which consists of a quartz thermometer* coupled to a digital comparator. $*$ * The signal from the quartz-crystal sensor located in the calibration tank (fig. 4b) is compared with a temperature set-point dialed on the comparator by the operator. Depending on the direction of temperature offset, the zomparator (fig. 6) switches the hot and cold solenoid valves on or off through relays designed to handle the necessary current. The quartz-thermometer digitalcomparator combination operates as a coupled system. Later, a digital-to-analogue converter and a Varian stripchart recorder (figs. 6, below, and 8 , page 17) were added to the control system to give a continuous and permanent record of tank temperature throughout any operation. Some advantages of the new system are: direct digital readout of tank temperature in degrees centigrade (one-second sampling rate with resolution to $0.001^{\circ} \mathrm{C}$ ); increased temperature range to include the $85^{\circ} \mathrm{C}$ required for reversing thermometer

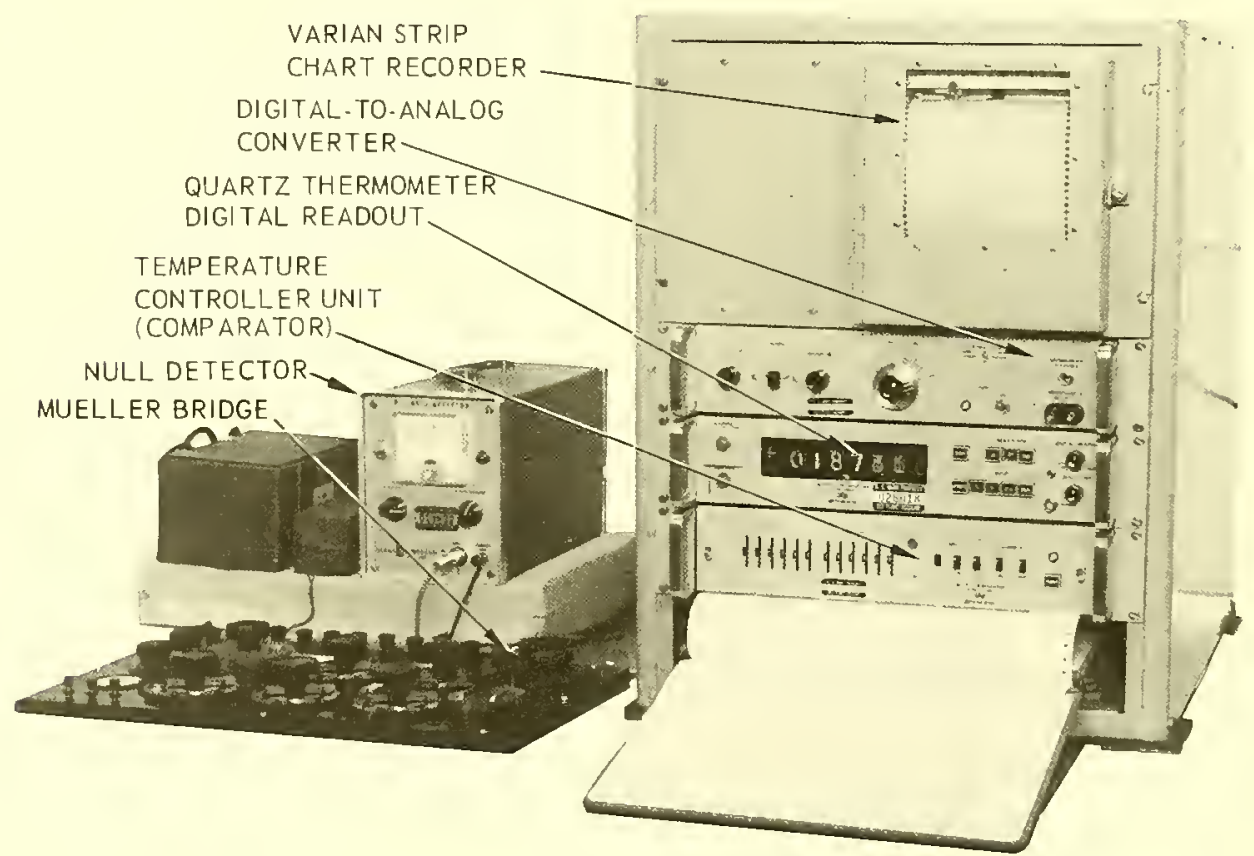

Figure 6. Temperature controller with Mueller bridge and null detector.

*DYMEC Quartz Thermometer Model $2801 \mathrm{~A}$.

**DYMEC Digital Comparator Model 2539 A. 
calibration; constant sensitivity throughout its range of use; continuous and permanent record of tank temperature during calibration; and reduction of mechanical parts in the control system that are subject to wear.

The old control system, ${ }^{1}$ retained as a backup, uses a pair of thermistors mounted in the calibration tank as temperature sensors. They comprise two arms of a Wheatstone bridge, the other two being a fixed resistor and a calibrated ten-turn potentiometer. The voltage resulting from an imbalance of the bridge is introduced to an amplifier which drives a servomotor. The rotational direction of the servomotor is dependent upon the direction of imbalance of the bridge. Coupled to the servomotor shaft is a slip-clutch cam that closes either of two microswitches mounted on opposite sides. These switches energize the hot and cold solenoid valves respectively. This system is limited by its design to a maximum of $35^{\circ} \mathrm{C}$. The minimum, with alcohol added, is $-4^{\circ} \mathrm{C}$. The system has no direct readout and cannot be used for quick checks of the tank temperature; however, it is capable of maintaining the bath temperature to within $\pm 0.002^{\circ} \mathrm{C}$ of any desired point throughout its range.

\section{THERMAL, SYSTEM IMPROVEMENTS}

Improvements have continually been made to the thermal system. The process of maintaining calibration tank temperatures below, but near to, that of the room requires the infrequent introduction of small quantities of cold water. Originally, during the periods of zero flow, the dormant water in the pipes absorbed heat from the room throughout the length of pipe from cold tank to solenoid. When the controller next opened the valve, water of the wrong temperature was thus introduced. A similar but opposite problem existed in the hot-water supply system. To remedy these problems a recirculating line (fig. 7) was installed in each of the external tanks. The pumps, which are gravity fed, now continuously force water of the proper temperature to a point as near as possible to the valves regulating induction to the calibration tank. If the solenoid valves are not open, the liquid is pumped back to the supply tanks via the recirculating lines. 
The original system used pumps constructed with a split collar integrally cast with the pump housing and clamped directly to a machined boss on the motor. The pump impeller was screwed directly to the armature; however, the large area at the junction of motor and pump housing allowed transfer of motor heat to the water within and the impeller passed an additional amount from the armature. The supply lines thus became filled, alternately, with warm and cold water. The problem was solved by replacing each unit with a separate pump joined to a motor with an insulating coupling, and the entire assembly was shock-mounted on a steel plate. The new motors operate at $3400 \mathrm{rpm}$ which is double their former speed, and they now run continuously instead of starting and stopping with the action of the solenoids. A small manually controlled needle valve (fig. 5) between the solenoid of each external supply and the main tank suffices for maintenance of a given temperature. For large changes, a 1/2-inch, quarter-

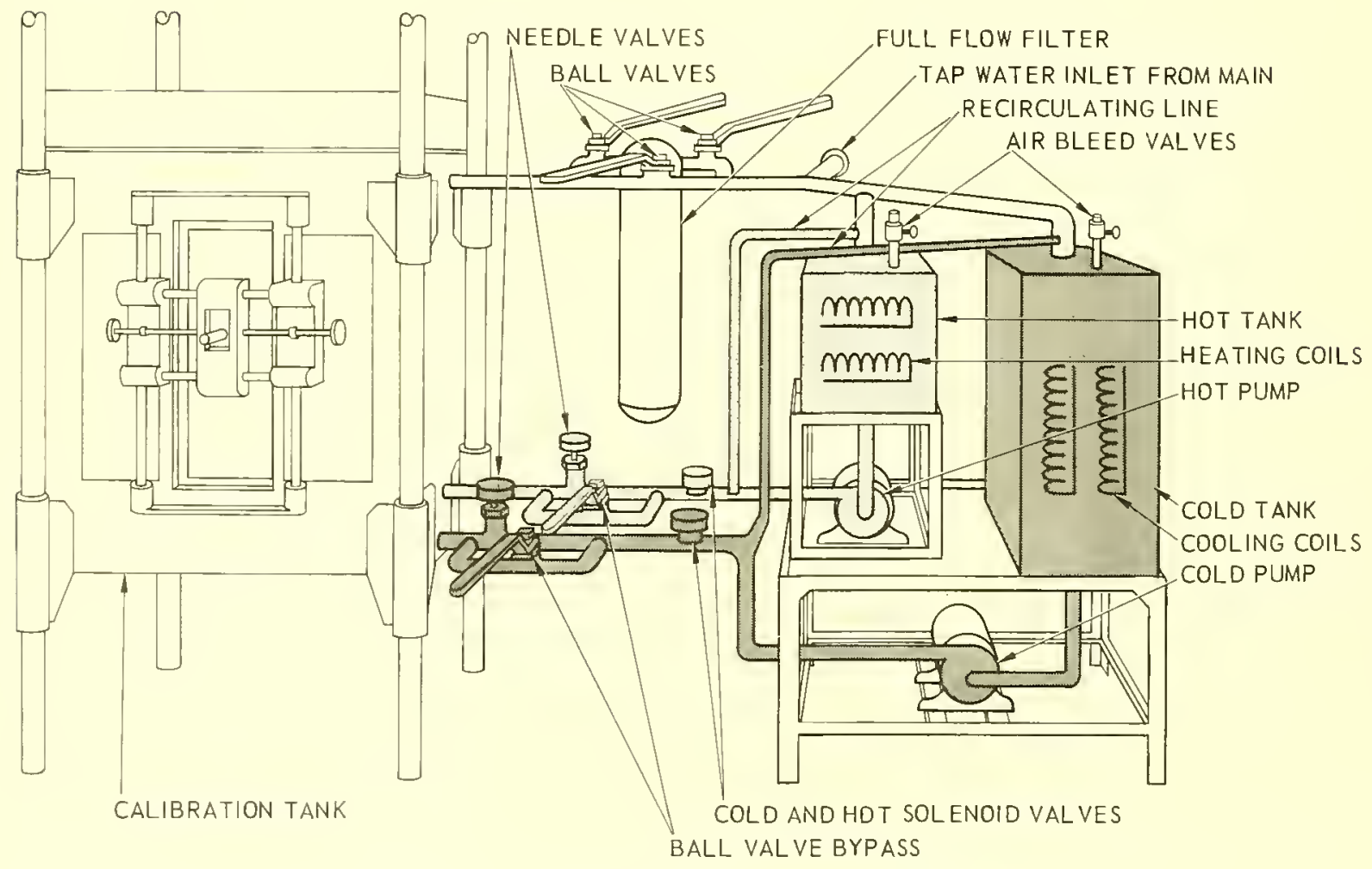

Figure 7. Sehematic of circulating system. 
turn, ball valve has been placed in each line bypassing the needle valves. Use of these allows more rapid transfer of water and has reduced the total time needed between calibration points.

\section{AIR CONDITIONING}

An air conditioning system was installed in the calibration room to maintain the air temperature within $\pm 2^{\circ} \mathrm{C}$. Previously, considerable changes in ambient temperature occurred throughout the day due to solar heating of the south wall. The atmospheric temperature stabilization in the room has now made control of the bath temperature to $\pm 0.002^{\circ} \mathrm{C}$ possible throughout an operation.

\section{ARRANGEMENT OF CONTROLS}

The controls for the calibration tank, the thermal system, temperature controller, and temperature standard are within easy reach of the operator (fig. 8). A large space immediately in front of the tank allows him to have easy access to the water even if he is working with bulky transducers and cumbersome bundles of cables. There is adequate room for recorders and resistance bridges used in the calibration of the instruments.

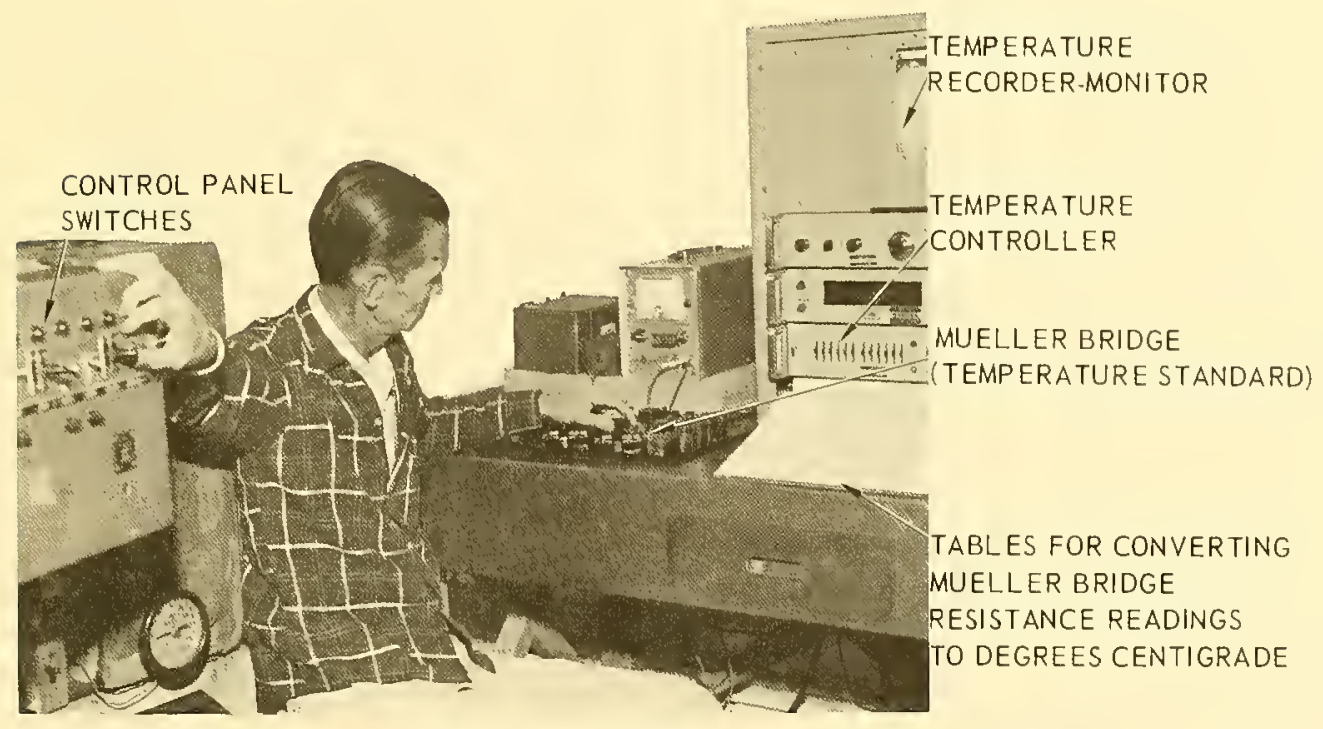

Figure 8. Access to oll controls by operator. 


\section{ARRANGEMENT OF EQUIPMENT}

The control panel (figs. 1 and 8) contains switches that actuate main power; tank illumination; thermostat; pump; lid elevation and lowering; indexing and reversing operations; and forward and rear stirrers. The panel is located on the right, front, tank-supporting leg and can be swung in a 270-degree arc to position it in the most convenient location for use at the control console or at the telescope.

An elapsed-time meter is installed on the control panel and electrically wired to one of the stirring motors. The ON time of the motor is more representative of actual calibration time than any of the other electrical components, and the meter is used to keep a record of the calibration times. The data are consulted for future work scheduling, to ensure completion of calibrations in time for ship sailing dates and other deadlines. In addition the data serve as a reminder of routine tank servicing needs, such as lubrication of motors, gears and linkages, and filter cartridge changes.

\section{FILTER}

A full-flow filter (fig. 5) is installed between the main tank return outlet and the thermal system. Ball valves are mounted at the two orifices of the filter and a pipe with another ball valve bypasses the assembly. With the ball valves closed and bypass open, the filter cartridges can be changed without halting tank operation. As the main tank nears its lower temperature limit, the cooling rate decreases due to the limitations of the refrigeration system. The filter bypass can then be opened to allow faster and larger flow across the refrigeration coils.

\section{TEMPERATURE STANDARD}

A Leeds and Northrup platinum resistance thermometer (fig. 4b) and an associated Mueller bridge Type G-2 
(fig. 6) are used as a standard. Both have been calibrated by the U.S. National Bureau of Standards, Washington, D. C.

Certain changes were made in this temperaturemeasuring system to improve its reliability, accuracy, and ease of use. An electronic dc null detector (fig. 6) was substituted for the original reflecting galvanometer. The advantages have been increased sensitivity, less zero drift, faster response, and absence of alignment and vibration problems associated with the light beam and prism system.

To check the Leeds and Northrup platinum resistance thermometer, a triple-point-of-water cell $*$ is used. This cell is based on the temperature when the solid, liquid, and vapor phases are in thermal equilibrium. The triplepoint temperature, fixed at $0.0100^{\circ} \mathrm{C}$, is more accurate and readily reproduced than an ice point. Immediately prior to use of the cell, the Mueller bridge is cleaned and the various controls are set according to the factory specifications. It is then calibrated with a Leeds and Northrup calibrating resistor of $10.01 \mathrm{ohms}$. This resistor has been certified by the U.S. National Bureau of Standards. The resistance of the platinum thermometer at the triple-point-of-water temperature is determined every three months.

\section{PRESSURE CHAIMBER}

A pressure vessel (fig. 9) for determining the $Q$ factor of unprotected deep-sea reversing thermometers was developed for use in the calibration tank. The $Q$ factor is defined as "the pressure coefficient of the unprotected thermometer expressed in degrees Celsius increase in the reading per $0.1 \mathrm{~kg} / \mathrm{cm}^{2}$ increase in pressure. "** The engineering features and operation of the vessel with its system of valves, tubes, pump, fluid medium separator, and deadweight pressure gage (fig. 10), will be described in detail in a future publication.

*EQUIPHASE Triple Point of Water CELL, TRANS-SONICS, Inc., Burlington, Mass.

**Hydrographic Office Publication No. 607 


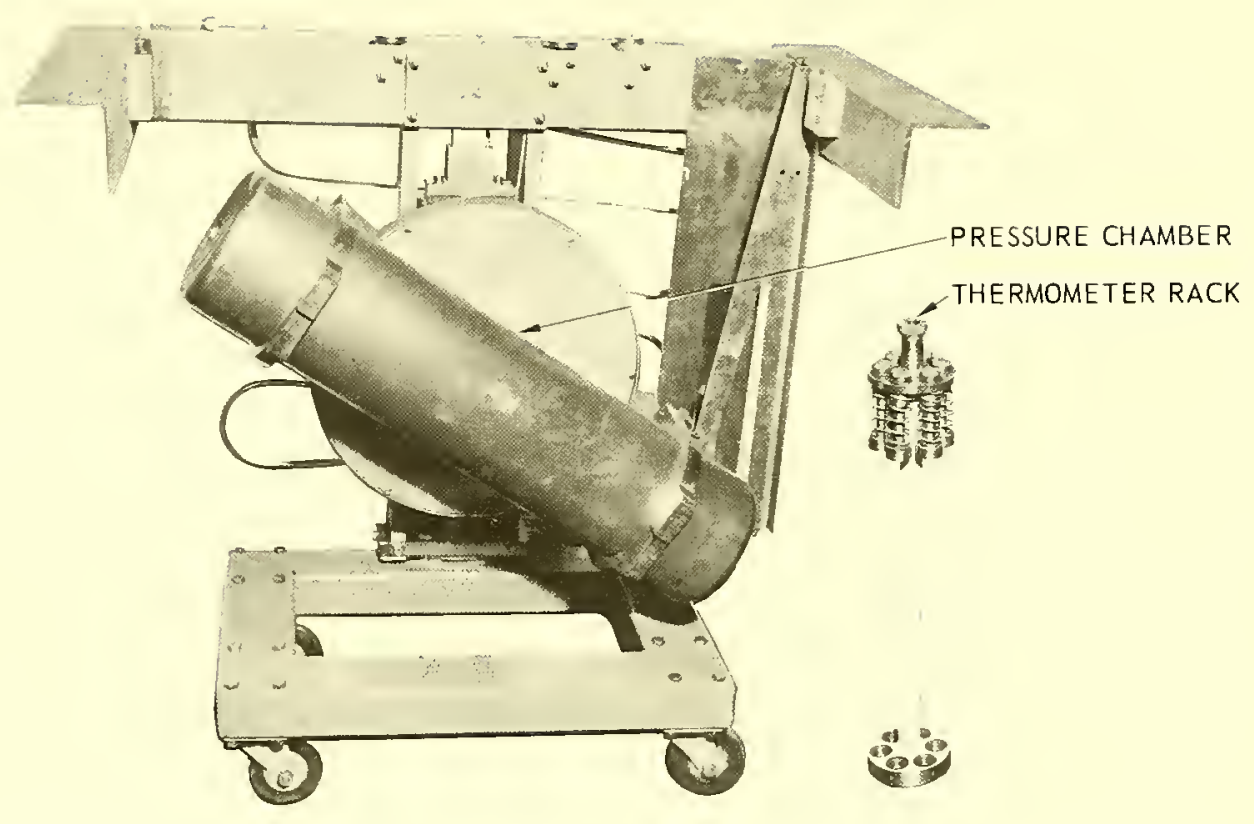

Figure 9. Pressure vessel far calibration of unpratected reversing thermameters.

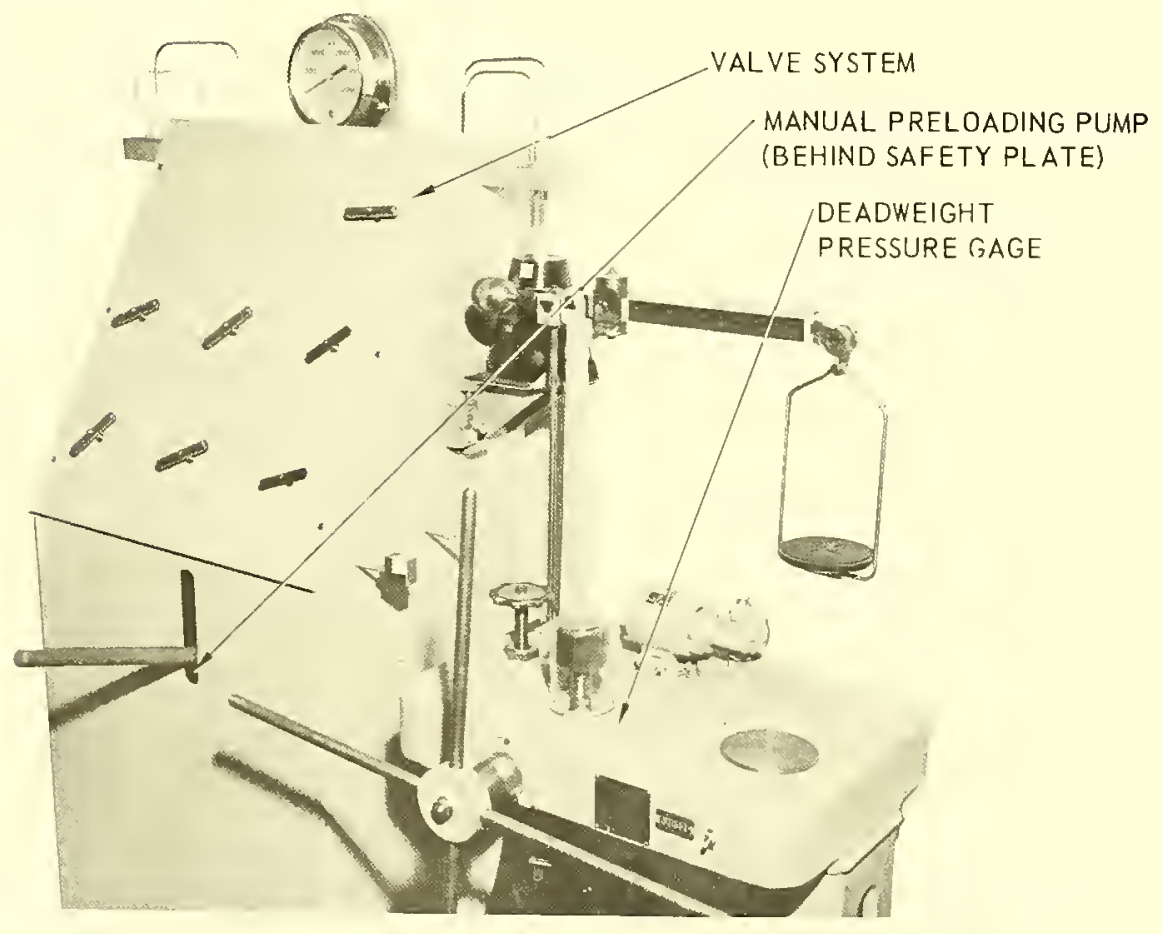

Figure 10. Deadweight pressure gage with hand pump and valving system. 


\title{
CALIBRATION OF REVERSING THERMOMETERS
}

\author{
SELECTION AND PREPARATION
}

Reversing thermometers are calibrated in groups of 24 with a reliable laboratory standard included in No. 1 position of the rack. All thermometers are first carefully inspected and reversed at room temperature to ensure that they will operate properly after insertion in the tank. Any which may require a slight tap to break the mercury column are positioned on either side of No. 1 where they can be reached easily after reversal. Identification numbers, storage numbers in the exercising rack (fig. 11), range, interval, original and latest $V_{o}, K, Q$, and owner, are listed on individual calibration sheets (fig. 12)。 The serial number on each thermometer is verified as it is placed in the tank rack.

The tank temperature is reduced to the lowest scale reading of the main stems prior to loading the thermometers in the rack. During the loading process the tank walls and insulation have time to stabilize (approximately

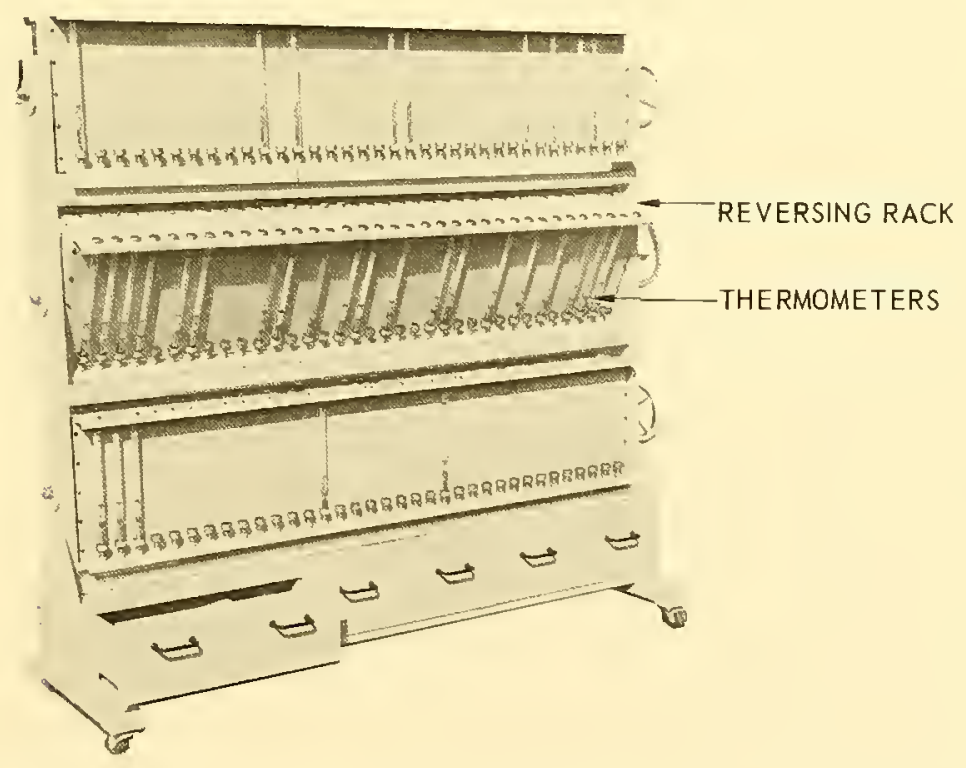

Figure 11. Exercising and storage rack for reversing thermometers. 


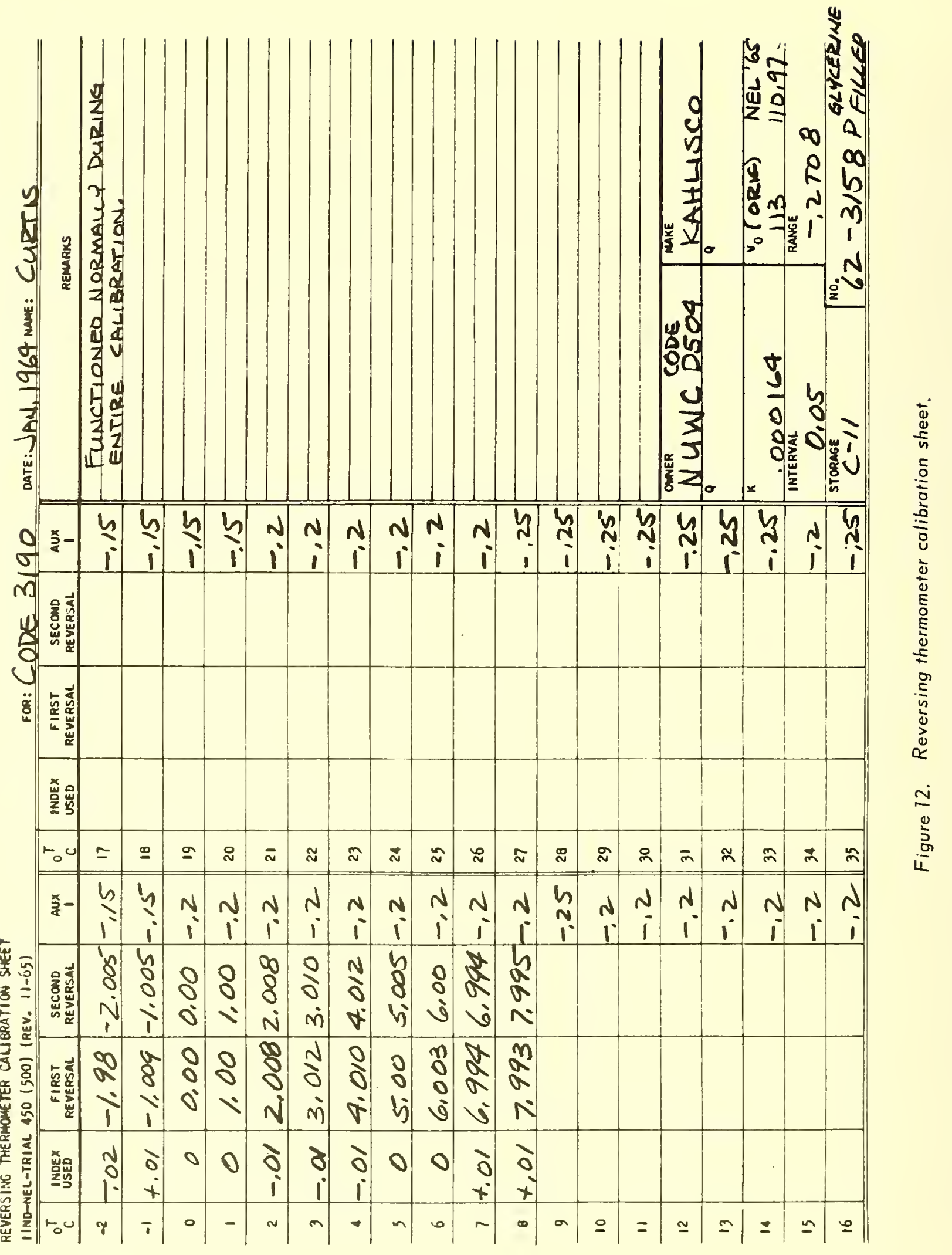


30 minutes), and the 20 gallons of water in the cold supply tank of the auxiliary system is cooled by the refrigerator to a temperature substantially below that in the main tank.

At the start of the calibration the Mueller bridge is checked and the ratio arms of the bridge are adjusted to equality if necessary. A warmup time of one-half hour is allowed for the null detector.

\section{SCALE CALIBRATION}

The thermometers are allowed to stabilize in the constant temperature bath for a period of at least 10 minutes before they are reversed. During this time the needle valve in the supply line is manually adjusted by the operator to permit continuous introduction of cold water at a rate that will exactly offset heat gain from the room through the tank walls. Temperatures during this last 10 -minute period are routinely held to $\pm 0.001^{\circ} \mathrm{C}$. The rack is reversed and the thermometers, both auxiliary and main, are read. The correction for the auxiliary is immediately logged in the AUXILIARY INDEX column of the data sheet, whereas the exact reading of the main is entered in the FIRST REVERSAL column.

After the reading, the rack is righted, and the drainage of mercury back to the original reservoir is aided, if necessary, by lifting the tank lid and bumping the thermometers in their respective spring-loaded cups. The temperature is again stabilized for 10 minutes, the rack reversed, and only the main stems read and recorded in the SECOND REVERSAL column. Tank temperature is then raised to the next desired point and the procedure is repeated.

$V_{0}$ DETERMINATION

The volume of mercury in the reservoir when the reading is $0^{\circ} \mathrm{C}$ is determined after the scale corrections have been completed. The thermometers are righted in the tank and the temperature lowered to $0^{\circ} \mathrm{C}$. After stabilizing they are reversed and read, then righted, the mercury is 
shaken down, and then they are stabilized, reversed, and read a second time. With the thermometers still reversed, the tank temperature is raised to $30^{\circ} \mathrm{C}$ and the increase in scale reading recorded for each instrument. Finally, the thermometers are removed from the tank and returned to storage.

\section{DATA REDUCTION}

The calibration sheets are completed by determining main stem corrections from the average of the two reversal readings. The $V_{0}^{\prime}$ 's are computed from the average of the two reversals at $0^{\circ} \mathrm{C}$, the rise after the second reversal at $30^{\circ} \mathrm{C}$, and the $K$ value.

\section{PROCEDURE FOR DETERMINING THE Q FACTOR}

The pressure factor, $Q$, of unprotected reversing thermometers is determined by use of a steel vessel in which six instruments can be held in pressure equilibrium with a sensitive deadweight balance (Crosby, Model CD-2).* The pressurized vessel can be rotated $180^{\circ}$ in a vertical plane while suspended in the constant temperature bath.

The rack holding 24 thermometers is removed from the tank and the pressure vessel lowered into it.

The outer glass jackets of six unprotected thermometers are filled with the alcohol-water mixture used in the tank. The mixture is retained in the thermometer by use of a rubber finger cot of suitable length to extend past the mounting holes after being rolled over the open end of the glass shell. Care is taken to exclude all air. The thermometers are placed in a circular rack (fig. 9) in an upright position and lowered into the pressure vessel, which can be opened at either end.

The vessel is sealed and an internal pressure of $100 \mathrm{~kg} / \mathrm{cm}^{2} \pm 0.25$ percent is applied and maintained. One hour is allowed at $0^{\circ} \mathrm{C}$ for temperature stabilization of the

\footnotetext{
*A Type $2400 \mathrm{H}$ RUSKA deadweight gage is now available.
} 
thermometers. (Experiments have shown this time to be adequate.) Then the vessel is reversed, the pressure is released, and the rack removed from the vessel and placed on a pivot behind the tank window. Here the thermometers are read through the telescope while still immersed in $0^{\circ} \mathrm{C}$ water. This procedure is followed twice at each pressure, and the tests are continued, increasing the pressure by increments of $100 \mathrm{~kg} / \mathrm{cm}^{2}$ to the limit of the thermometer scales. The $Q$ factor is determined from the readings and the data noted on the individual calibration sheets.

\section{DISTRIBUTION}

All original calibration sheets are kept at this Center to form histories of each thermometer. A Xerox copy of the most recent calibration data sheet is issued with each instrument.

\section{THERMOMETER CARE}

Thermometers are stored in a special reversing rack which holds 210 thermometers in a vertical position (fig. 11). They are reversed weekly to keep the mercury flowing freely through the capillary. Seventy thermometers can be tripped simultaneously.

\section{CALIBRATION OF OTHER SENSORS}

The NUWC Temperature Calibration Facility is being increasingly used to calibrate oceanographic devices other than deep-sea reversing thermometers, for example, thermistor beads. Forty-eight of these heat-sensing probes are spread along the NUWC Thermistor Chain, which is suspended from the fantail of the oceanographic research vessel USS MARYSVILLE and used in the study of the temperature structure of the oceans. In addition, numerous vertical and horizontal arrays of temperature sensors are 
used in the water adjacent to the NUWC Oceanographic Research Tower. ${ }^{3}$

THERMISTOR BEADS

These thermal sensors are acquired in lots up to a quantity of 1000 . They are encapsulated by the manufacturer in a sealed glass envelope 2 inches long by $1 / 8$ inch in diameter, and have a nominal resistance of $2000 \mathrm{ohms}$ at $25^{\circ} \mathrm{C}$. Upon delivery to the Center the beads are individually identified with wire labels and suspended in the calibration tank for a resistance determination at two or more temperatures. An automatic balance resistance bridge* is used for this purpose (fig. 13). On the basis of the data obtained,

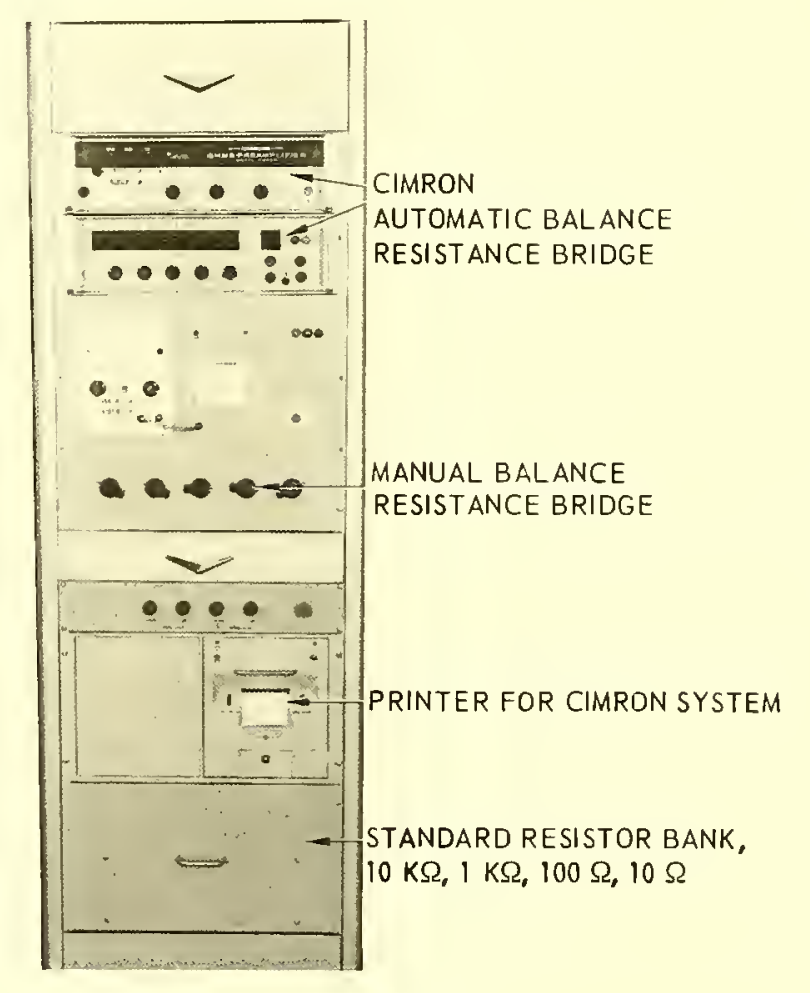

Figure 13. Resistance bridge for calibrating thermistors.

${ }^{3}$ Navy Electronics Laboratory Report 1342, The U.S. Navy Electronics Laboratory's Oceanographic Research Tower, by E. C. LaFond, 22 December 1965

* CIMRON ohms-preamplifier, Model 6869B and CIMRON voltmeter, Model P9400B 
several matched sets of 50 each are selected to be used with the oceanographic chain. The groups of 50 are encapsulated with epoxy resin in a Lucite form of the proper shape to fit the mounting holes in the thermistor chain fairings.

The completed probes are then recalibrated at $0^{\circ}, 3^{\circ}, 10^{\circ}, 15^{\circ}, 20^{\circ}, 25^{\circ}$, and $30^{\circ} \mathrm{C}$. The information is used to determine the resistance padding to be used in the bridge circuit of the chain recorder so as to bring all circuits to the same resistance at a given temperature.

Finally, the time constant of each probe is determined. The lag is built in during the potting process by allowing the compound to cover the end of each bead to a uniform thickness ( 0.010 inch). The time constants are measured by using two baths, first stabilizing the beads in a low-temperature bath, then plunging them into a hightemperature bath. The lag time is defined as the time required to reach 63 percent of the temperature change.

\section{SOUND-VELOCITY METERS}

The calibration tank must be specially prepared for the calibration of sound-velocity meters. It is first drained of the alcohol-water mixture, scrubbed, and rinsed. The hot and cold tanks are similarly purged. The tank system is then filled with distilled water. The water is circulated for several hours and kept in the tank overnight. The system is again drained to flush any possible contaminant and refilled with distilled water. After these preparations, salt contamination never exceeds 15 parts per million, which is well below the concentration that could affect sound velocity values.

The sound-velocity meters are calibrated, up to three at a time, after their cables and brackets have been scrubbed and rinsed in distilled water. When distilled water is being circulated and cooled by the thermal system. its lower temperature limit has to be set just above $0^{\circ} \mathrm{C}$ to prevent icing of the refrigeration coils. With a maximum flow from the cold tank, a minimum temperature of $0.8^{\circ} \mathrm{C}$ can be maintained in the calibration tank. The calibration begins at that point and continues from $1^{\circ} \mathrm{C}$ through $30.0^{\circ} \mathrm{C}$ 
at each whole-degree interval. Three frequency readings are taken on a counter during each step at the even degrees. Ten minutes are allowed at each point for stabilization of the sound-velocity meter heads before readings are taken.

\section{CONCLUSIONS}

1. The NUWC Calibration Facility has furnished vital support to oceanographic research groups.

2. The improvements of the mechanical system, and the addition of a pressure-testing unit, have made the facility more versatile.

3. Assignment of one operator, with a designated alternate, to the facility has resulted in efficient operation and reliable data.

4. The facility, because of increased demands for reliable temperature calibration, is now in full-time operation.

\section{RECOMMENDATIONS}

1. Utilize the calibration tank for precise temperature calibration and for studies that require constant temperature.

2. Continue development directed toward improving the mechanical, electrical, and electronic components of the facility. 


\section{APPENDIX: RESULTS OF CROSS-CALIBRATION PROGRAM}

In the spring of 1966 the U.S. Navy Oceanographic Office initiated an interorganizational, cross-calibration program for deep-sea reversing thermometers. The purpose was to compare data and determine the cause of any differences in results. Three laboratories joined NAVOCEANO in this endeavor, namely, Naval Undersea Warfare Center (NUWC), Woods Hole Oceanographic Institution (WHOI), and Scripps Institution of Oceanography (SIO).

Twenty-four thermometers with histories of reliability were selected for the program. These were divided into four groups, each containing six instruments of similar type and range (table A1). The thermometers were hand-carried between laboratories in a shock-proof protective case. The calibration program was started in early June 1966 and completed in December 1966.

TABLE A1. THERMOMETER GROUPING.

\begin{tabular}{c|c|c|c} 
Group & Range & Type & Test Point Temperatures, ${ }^{\circ} \mathrm{C}$ \\
\hline I & -2 to $6{ }^{\circ} \mathrm{C}$ & Protected & $-2,0,2,4,6$ \\
\hline II & -2 to $15^{\circ} \mathrm{C}$ & Protected & $-2,0,2,4,6,8,10,12.5,15$ \\
\hline III & -2 to $30^{\circ} \mathrm{C}$ & Protected & $-2,0,2,4,6,8,10,12.5,15,20.25 .30$ \\
\hline IV & -2 to $30^{\circ} \mathrm{C}$ & Unprotected & $-2,0,2,4,6,8,10,12.5,15,20,25.30$
\end{tabular}

$V_{o}$ determination: initial reading $0^{\circ} \mathrm{C}$, expansion reading $30^{\circ} \mathrm{C}$

$Q$ factors at $100 \mathrm{kgm} / \mathrm{cm}^{2}, 200 \mathrm{kgm} / \mathrm{cm}^{2}$, and $300 \mathrm{kgm} / \mathrm{cm}^{2}$

Upon completion of the calibrations, all data were exchanged between laboratories. The largest differences noted (tables A4 - A7) appeared to be due to the different types of standards used, namely, platinum resistance thermometers by NOO and NUWC and mercury-in-glass thermometers by WHOI and SIO (table A2). As a first step toward improving future cross-calibration results, all participants agreed to use triple-point-of-water cells to check the zero point of their standards. Tolerances were 


\section{TABLE A2. COMPARISON OF LABORATORIES' FACILITIES}

\begin{tabular}{|c|c|c|c|c|c|}
\hline Laboratory & $\begin{array}{l}\text { Tank capacity } \\
\text { (gallons) }\end{array}$ & $\begin{array}{l}\text { Type of temperature } \\
\text { standard used }\end{array}$ & $\begin{array}{l}\text { Automatic } \\
\text { temperature } \\
\text { control }\end{array}$ & $\begin{array}{c}\text { Thermometer } \\
\text { rack } \\
\text { capacity }\end{array}$ & $\begin{array}{c}\text { Pressure } \\
\text { vessel }\end{array}$ \\
\hline $\begin{array}{l}\text { U.S. Navy } \\
\text { Oceanographic } \\
\text { Office }\end{array}$ & 55 & $\begin{array}{l}\text { Platinum thermometer } \\
\text { with Mueller Bridge }\end{array}$ & yes & 24 & yes \\
\hline $\begin{array}{l}\text { U.S. Navy Undersea } \\
\text { Warfare Center }\end{array}$ & 70 & $\begin{array}{l}\text { Platinum thermometer } \\
\text { with Mueller Bridge }\end{array}$ & yes & 24 & yes \\
\hline $\begin{array}{l}\text { Woods Hole } \\
\text { Oceanographic } \\
\text { Institution }\end{array}$ & 70 & $\begin{array}{l}\text { Mercury-in-glass } \\
\text { thermometer }^{1}\end{array}$ & yes & $18^{2}$ & yes \\
\hline $\begin{array}{l}\text { Scripps Institution } \\
\text { of Oceanography }\end{array}$ & 32 & $\begin{array}{l}\text { Mercury-in-glass } \\
\text { thermometer }\end{array}$ & no & 24 & no $^{3}$ \\
\hline $\begin{array}{l}\text { Kahl Scientific } \\
\text { Instrument Co. }\end{array}$ & 26 & $\begin{array}{l}\text { Mercury-in-glass } \\
\text { thermometer }\end{array}$ & no & 8 & yes \\
\hline
\end{tabular}

${ }^{1}$ WHOI and Kahl standards are specially made mercury-in-glass thermometers of materials and physical dimensions similar to those of protected deep-sea reversing thermometers. Because of these similarities, the time constants of the standards are the same as those of the instruments being tested.

${ }^{2}$ WHOI calibration tank rack has a capacity of 18 thermometers compared with 24 for the other three laboratories. The data contributed by WHOI for their Group l $\left(-2\right.$ to $\left.6^{\circ} \mathrm{C}\right)$ instruments were taken in March 1966.

${ }^{3} Q$ data from SIO for Group IV unprotected type were taken at sea by lowering the thermometers to the required depth and reversing them with other instruments of known calibration and proven reliability.

established for future calibration programs for scale readings, $V_{o}$ values, and $Q$ factors (table $A 3$ ). It was agreed that the program should continue.

Kahl Scientific Instrument Company, El Cajon, California, expressed an interest in the calibration data and, in February 1967, furnished scale corrections, $V_{0}$ 's and $Q$ factors of the Group IV thermometers in exchange for all data from the other laboratories.

TABLE A3. CROSS-CALIBRATION TOLERANCES TO BE USED FOR FUTURE WORK

\begin{tabular}{c|c|c} 
Scale reading & \multicolumn{1}{|c|}{$V_{o}$ values } & \multicolumn{1}{c}{$Q$ factor } \\
\hline $1 / 10$ of smallest division & $\begin{array}{l} \pm .0^{\circ} \mathrm{C} \text { for ranges below } \\
15^{\circ} \mathrm{C} \text { and } \pm 2.0^{\circ} \mathrm{C} \text { for } \\
\text { ranges of } 15^{\circ} \mathrm{C} \text { and above }\end{array}$ & $\begin{array}{l} \pm 0.00002^{\circ} \mathrm{C} / \\
\text { hectogram } / \mathrm{cm}^{2} \\
\left(0.00002^{\circ} \mathrm{C} / \text { meter }\right. \\
\text { depth })\end{array}$ \\
&
\end{tabular}


TABLE A4. THERMOMETER CROSS CALIBRATION.

Scale corrections in thousandths of a degree C. Group I $\left(-2\right.$ to $\left.6^{\circ} \mathrm{C}\right)$.

Protected type thermometers.

Mfg: All Richter \& Wiese.

Serial No. 10254

Serial No. 10255

Temperature NOO NEL WHOI SIO Temperature NOO NEL WHOI SIO

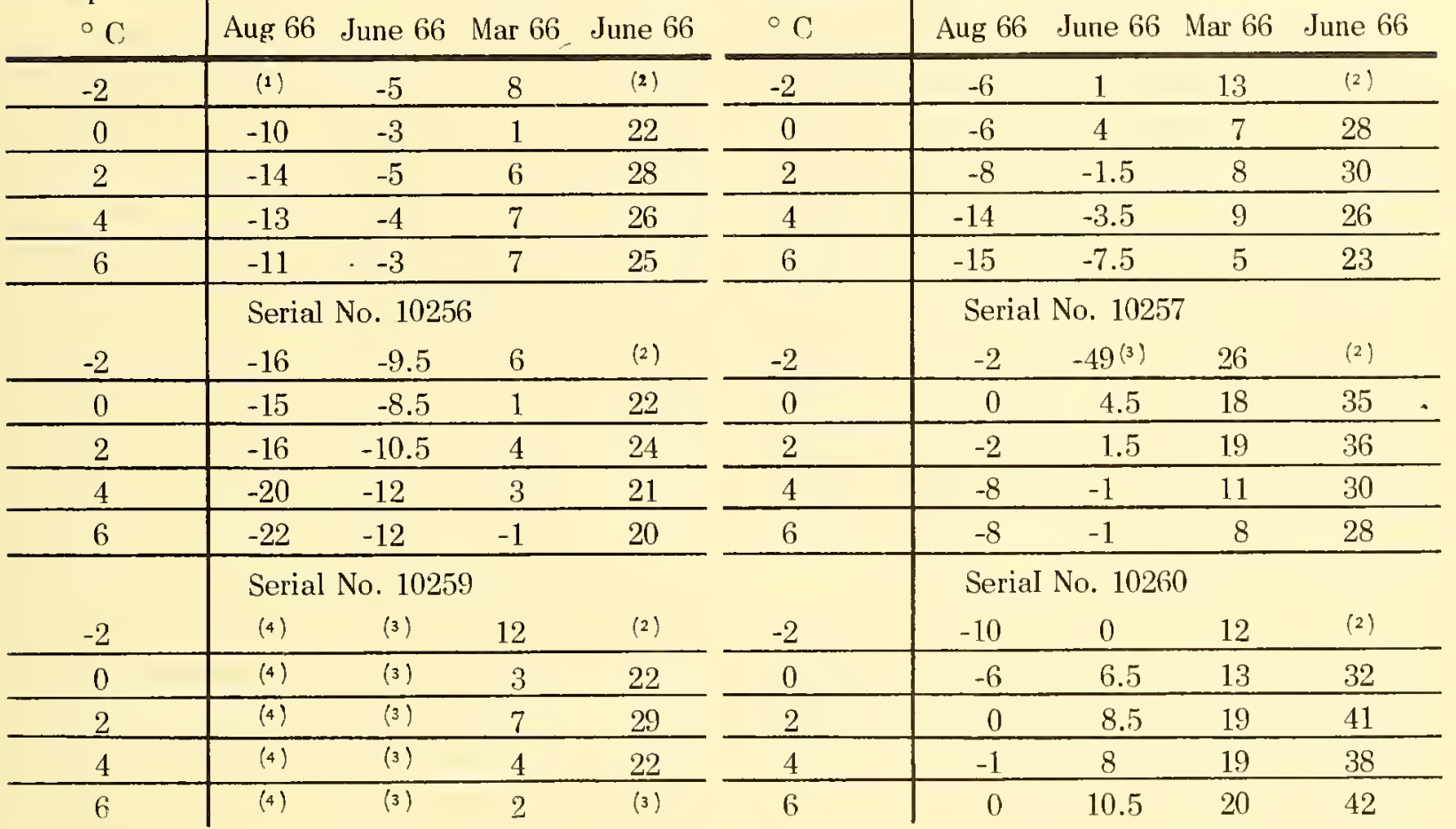

(1) Erratic

(2) No data furnished

(3) Thermometer malfunction

(4) Gas 
Scale corrections in thousandths of a degree C. Group II $\left(-2\right.$ to $\left.15^{\circ} \mathrm{C}\right)$.

Protected type thermometers.

Mfg: Franz Schmidt (FS), Richter \& Wiese (R\&W), Kahlsico (Kahl).

FS Serial No. 3056

Temperature NOO NEL WHOI SIO \begin{tabular}{l|lll}
${ }^{\circ} \mathrm{C}$ & Aug 66 June 66 Oct 66 June 66
\end{tabular}

\begin{tabular}{c|rrrr}
\hline-2 & -14 & $-239^{(1)}$ & 1 & $(2)$ \\
\hline 0 & -12 & -9 & 0 & 19 \\
\hline 2 & -10 & -7 & 17 & 25 \\
\hline 4 & -47 & -47 & -21 & -11 \\
\hline 6 & -55 & -50 & -31 & -16 \\
\hline 8 & -58 & -53 & -36 & -21 \\
\hline 10 & -58 & -56 & -43 & -28 \\
\hline 12.5 & -54 & -52 & -44 & -20 \\
\hline 15 & -38 & -34 & -23 & -8 \\
\hline
\end{tabular}

Kahl Serial No. 56-1596

\begin{tabular}{c|rrrr}
-2 & -28 & -24 & -9 & (2) \\
\hline 0 & -18 & -13 & -4 & 18 \\
\hline 2 & -18 & -14 & 4 & 22 \\
\hline 4 & -13 & -11 & 8 & 22 \\
\hline 6 & -16 & -12 & 5 & 22 \\
\hline 8 & -2 & 0 & 18 & 37 \\
\hline 10 & 21 & 23 & 37 & 55 \\
\hline 12.5 & 9 & 17 & 24 & 48 \\
\hline 15 & -6 & -3 & 1 & 22 \\
\hline
\end{tabular}

Kahl Serial No. 56-1635

\begin{tabular}{c|rrrr}
$\begin{array}{c}\text { Temperature } \\
{ }^{\circ} \mathrm{C}\end{array}$ & $\begin{array}{c}\text { NOO } \\
\text { Aug } 66\end{array}$ & $\begin{array}{c}\text { NEL } \\
\text { June } 66\end{array}$ & $\begin{array}{c}\text { WHOI } \\
\text { Oct } 66\end{array}$ & $\begin{array}{c}\text { SIO } \\
\text { June 66 }\end{array}$ \\
\hline-2 & ${ }^{(3)}$ & ${ }^{(3)}$ & ${ }^{(3)}$ & $(2)$ \\
\hline 0 & -40 & -27 & -25 & -2 \\
\hline 2 & -28 & -22 & -6 & 14 \\
\hline 4 & -8 & -1 & 13 & 28 \\
\hline 6 & -6 & 0 & 14 & 31 \\
\hline 8 & -6 & 0 & 12 & 31 \\
\hline 10 & -6 & 0 & 9 & 28 \\
\hline 12.5 & -4 & 0 & 4 & 30 \\
\hline 15 & 0 & 13 & 12 & 34
\end{tabular}

(1) Thermometer malfunction

(2) No data furnished

(3) Off scale
R\&W Serial No. 5193

\begin{tabular}{c|cccc}
$\begin{array}{c}\text { Temperature } \\
{ }^{\circ} \mathrm{C}\end{array}$ & $\begin{array}{c}\text { NOO } \\
\text { Aug 66 }\end{array}$ & $\begin{array}{c}\text { NEL } \\
\text { June } 66\end{array}$ & $\begin{array}{c}\text { WHOI } \\
\text { Oct 66 }\end{array}$ & $\begin{array}{c}\text { SIO } \\
\text { June 66 }\end{array}$ \\
\hline-2 & -63 & -60.5 & -50 & $(2)$ \\
\hline 0 & -60 & -54 & -49 & -29 \\
\hline 2 & -62 & -53 & -36 & -24 \\
\hline 4 & -60 & -53 & -39 & -26 \\
\hline 6 & -64 & -58 & -44 & -30 \\
\hline 8 & -61 & -56 & -40 & -27 \\
\hline 10 & -57 & -53 & -43 & -29 \\
\hline 12.5 & -64 & -62 & -55 & -34 \\
\hline 15 & -62 & -56 & -52 & -36 \\
\hline
\end{tabular}

Kahl Serial No. $56-1630$

\begin{tabular}{c|rrrr}
-2 & -50 & -50 & -35 & $(2)$ \\
\hline 0 & -52 & -50 & -33 & -16 \\
\hline 2 & -50 & -50 & -28 & -10 \\
\hline 4 & -38 & -28 & -12 & 0 \\
\hline 6 & -30 & -24 & -7 & 11 \\
\hline 8 & -25 & -24 & -8 & 10 \\
\hline 10 & -18 & -13 & -1 & 15 \\
\hline 12.5 & -19 & -20 & -10 & 11 \\
\hline 15 & -1 & 0 & 10 & 28 \\
\hline
\end{tabular}

Kahl Serial No. 64-3989

Temperature NOO NEL WHOI SIO

\begin{tabular}{c|rrrr}
${ }^{\circ} \mathrm{C}$ & Aug 66 & June 66 & Oct 66 & June 66 \\
\hline-2 & -7 & -18 & 6 & $(2)$ \\
\hline 0 & -2 & -4 & -8 & 19 \\
\hline 2 & 0 & -3 & 25 & 25 \\
\hline 4 & -2 & -3 & 24 & 22 \\
\hline 6 & 0 & 0 & 26 & 28 \\
\hline 8 & -1 & 12 & 30 & 32 \\
\hline 10 & 1 & 8 & 22 & 24 \\
\hline 12.5 & -8 & -2 & 3 & 11 \\
\hline 15 & -11 & -5 & 0 & 7
\end{tabular}


TABLE A4 (Continued)

Scale corrections in thousandths of a degree C. Group III (-2 to $\left.30^{\circ} \mathrm{C}\right)$.

Protected type thermometers.

Mfg: All KahIsico.

Serial No. 1459-66

Serial No. 1470-66

\begin{tabular}{c|cccc}
$\begin{array}{c}\text { Temperature } \\
\circ \mathrm{C}\end{array}$ & NOO & NEL & WHOI & SIO \\
& Aug 66 & June 66 & Oct 66 & June 66 \\
\hline-2 & 1 & 6 & 20 & $(1)$ \\
\hline 0 & -10 & 0 & 0 & 26 \\
\hline 2 & -20 & -8 & 0 & 23 \\
\hline 4 & -26 & -17 & -5 & 16 \\
\hline 6 & -33 & -21 & -10 & 13 \\
\hline 8 & -35 & -26 & -15 & 7 \\
\hline 10 & -32 & -25 & -20 & 6 \\
\hline 12.5 & -37 & -27 & -25 & 4 \\
\hline 15 & -32 & -27 & -20 & 4 \\
\hline 20 & -28 & -20 & -30 & 11 \\
\hline 25 & -31 & -28 & -30 & -1 \\
\hline 30 & -35 & -34 & -35 & -6 \\
\hline
\end{tabular}

Serial No. 1462-66

\begin{tabular}{|c|c|c|c|c|c|c|c|c|c|}
\hline-2 & -5 & 0 & 5 & (1) & -2 & 0 & 3 & 15 & (1) \\
\hline 0 & -6 & 0 & 5 & 28 & 0 & -4 & 0 & 0 & 29 \\
\hline 2 & -16 & -9 & 5 & 23 & 2 & -9 & 0 & 5 & 27 \\
\hline 4 & -22 & -15 & 0 & 16 & 4 & -13 & -4 & 0 & 20 \\
\hline 6 & -16 & -8 & 5 & 18 & 6 & -13 & -3 & 0 & 20 \\
\hline 8 & -10 & -3 & 5 & 29 & 8 & -16 & -14 & 0 & 21 \\
\hline 10 & -5 & -1 & 5 & 27 & 10 & -20 & -13 & -5 & 15 \\
\hline 12.5 & -3 & 0 & 5 & 31 & 12.5 & -25 & -19 & -15 & 10 \\
\hline 15 & -2 & 2 & 5 & 31 & 15 & -27 & -23 & -15 & 7 \\
\hline 20 & 0 & 0 & 5 & 34 & 20 & -14 & -9 & -15 & 19 \\
\hline 25 & -16 & -10 & -10 & 15 & 25 & -20 & -15 & -20 & 11 \\
\hline 30 & -18 & -18 & -15 & 7 & 30 & -28 & -28 & -30 & 0 \\
\hline
\end{tabular}

(1) No data furmished 
TABLE A4 (Continued)

Scale corrections in thousandths of a degree C. Group III $\left(-2\right.$ to $\left.30^{\circ} \mathrm{C}\right)$.

Protected type thermometers.

Mfg: All Kahlsico.

Serial No. 1484-66

Serial No. 1486-66

\begin{tabular}{|c|c|c|c|c|c|c|c|c|c|}
\hline $\begin{array}{c}\text { Temperature } \\
{ }^{\circ} \mathrm{C} \\
\end{array}$ & $\begin{array}{c}\text { NOO } \\
\text { Aug } 66\end{array}$ & $\begin{array}{c}\text { NEL } \\
\text { June } 66\end{array}$ & $\begin{array}{l}\text { WHOI } \\
\text { Oct } 66\end{array}$ & $\begin{array}{c}\text { SIO } \\
\text { June } 66 \\
\end{array}$ & $\begin{array}{l}\text { Temperature } \\
{ }^{\circ} \mathrm{C} \\
\end{array}$ & $\begin{array}{l}\text { NOO } \\
\text { Aug } 66 \\
\end{array}$ & $\begin{array}{c}\text { NEL } \\
\text { June } 66 \\
\end{array}$ & $\begin{array}{l}\text { WHOI } \\
\text { Oct } 66 \\
\end{array}$ & $\begin{array}{c}\text { SIO } \\
\text { June } 66 \\
\end{array}$ \\
\hline-2 & 4 & 11 & 20 & (1) & -2 & 4 & 7 & 25 & (1) \\
\hline 0 & -4 & 0 & 5 & 23 & 0 & 2 & 20 & 15 & 47 \\
\hline 2 & -12 & -11 & 5 & 23 & 2 & 1 & 15 & 35 & 51 \\
\hline 4 & -20 & -17 & 0 & 14 & 4 & -1 & 5 & 25 & 42 \\
\hline 6 & -22 & -21 & -5 & 13 & 6 & 0 & 7 & 25 & 41 \\
\hline 8 & -25 & -24 & -5 & 11 & 8 & -2 & 0 & 15 & 34 \\
\hline 10 & -13 & -16 & 0 & 13 & 10 & -2 & 0 & 5 & 29 \\
\hline 12.5 & -19 & -20 & -10 & 11 & 12.5 & -2 & 0 & 0 & 27 \\
\hline 15 & -16 & -18 & -10 & 12 & 15 & -1 & 0 & 5 & 29 \\
\hline 20 & -10 & -3 & -10 & 22 & .20 & 0 & 3 & 5 & 39 \\
\hline 25 & -10 & -7 & -5 & 17 & 25 & -5 & 0 & 0 & 28 \\
\hline 30 & -23 & -27 & -20 & 4 & 30 & -2 & 0 & -10 & 15 \\
\hline
\end{tabular}

(1) No data furnished 
Scale corrections in thousandths of a degree C. Group IV $\left(-2\right.$ to $30^{\circ} \mathrm{C}$.

Unprotected type thermometers.

Mfg: All Kessler.

NEL recalibration data of Mar 67 include a $0.002^{\circ} \mathrm{C}$ increase due to recalibration of the platinum standard used in the bath.

Kessler Serial No. 598-64

Recali-

bration

\begin{tabular}{c|cccccc}
$\begin{array}{c}\text { Temperature } \\
{ }^{\circ} \mathrm{C}\end{array}$ & NOO & NEL & WHOI & SIO & KAHL & NEL \\
& Aug 66 & June 66 & Mar 66 & June 66 & Feb 67 & Mar 67 \\
\hline-2 & -48 & -50 & -40 & $(1)$ & (1) & -52 \\
\hline 0 & -38 & -42 & -15 & -6 & -20 & -44 \\
\hline 2 & -42 & -44 & -15 & -3 & 0 & -42 \\
\hline 4 & -48 & -48 & -20 & -6 & 0 & -48 \\
\hline 6 & -46 & -48 & -20 & -11 & -10 & -50 \\
\hline 8 & -44 & -48 & -25 & -15 & -10 & -50 \\
\hline 10 & -43 & -46 & -20 & -9 & -15 & -43 \\
\hline 12.5 & -20 & -23 & -5 & 14 & 10 & -24 \\
\hline 15 & -11 & -11 & -5 & 19 & -20 & -9 \\
\hline 20 & -9 & -5 & 0 & 25 & 15 & 0 \\
\hline 25 & -12 & -17 & -5 & 15 & 10 & -7 \\
\hline 30 & -23 & -30 & -15 & 5 & 0 & -23 \\
\hline
\end{tabular}

Kessler Serial No. 458-64

\begin{tabular}{c|rrrrrr} 
& -39 & -43 & 35 & $(1)$ & $(1)$ & -45 \\
\hline 0 & -47 & -46 & -25 & $(2)$ & 0 & -49 \\
\hline 2 & -50 & -48 & -20 & -7 & 0 & -48 \\
\hline 4 & -46 & -47 & -15 & -8 & 0 & -45 \\
\hline 6 & -44 & -46 & -15 & -6 & 0 & -47 \\
\hline 8 & -46 & -48 & -25 & -12 & 0 & -48 \\
\hline 10 & -50 & -50 & -30 & -15 & -15 & -51 \\
\hline 12.5 & -38 & -40 & -20 & -3 & 0 & -38 \\
\hline 15 & -28 & -28 & -10 & 4 & 0 & -28 \\
\hline 20 & -10 & -8 & 0 & 25 & 10 & -5 \\
\hline 25 & -13 & -22 & -5 & 15 & 10 & -14 \\
\hline 30 & -32 & -47 & -25 & -6 & 0 & -33
\end{tabular}

(1) No data furnished

(2) Below scope limit

(3) Covered

(4) Obscured

(5) No scale 
Scale corrections in thousandths of a degree C. Group IV ( -2 to $\left.30^{\circ} \mathrm{C}\right)$.

Unprotected type thermometers.

Mfg: All Kessler.

NEL recalibration data of Mar 67 include a $0.002^{\circ} \mathrm{C}$ increase due to recalibration of the platinum standard used in the bath.

Kessler Serial No. 467-64

Recali-

bration

\begin{tabular}{c|cccccc}
$\begin{array}{c}\text { Temperature } \\
{ }^{\circ} \mathrm{C}\end{array}$ & NOO & NEL & WHOI & SIO & KAHL & NEL \\
Aug 66 & June 66 & Mar 66 & June 66 & Feb 67 & Mar 67 \\
\hline-2 & -56 & -55 & -50 & $(\mathbf{1})$ & (1) & -59 \\
\hline 0 & -50 & -50 & -15 & $(2)$ & -30 & -51 \\
\hline 2 & -38 & -40 & -10 & 1 & 0 & -41 \\
\hline 4 & -23 & -22 & 5 & 18 & 30 & -22 \\
\hline 6 & -4 & -1 & 15 & 32 & 40 & -3 \\
\hline 8 & -2 & 0 & 25 & 43 & 50 & 1 \\
\hline 10 & 1 & 0 & 25 & 44 & 50 & 11 \\
\hline 12.5 & -2 & -3 & 5 & 30 & 40 & -2 \\
\hline 15 & -20 & -20 & -5 & 15 & 0 & -22 \\
\hline 20 & -40 & -43 & -35 & -4 & -10 & -38 \\
\hline 25 & -30 & -35 & -25 & -3 & 0 & -28 \\
\hline 30 & -32 & -41 & -25 & -6 & 0 & -34 \\
\hline
\end{tabular}

Kessler Serial No. 601-64

\begin{tabular}{c|rrrrrr}
\hline-2 & -34 & -28 & -25 & $(1)$ & $(1)$ & -29 \\
\hline 0 & -40 & -38 & -20 & -5 & -20 & -42 \\
\hline 2 & -60 & -53 & -30 & -19 & -15 & -53 \\
\hline 4 & -65 & -58 & -40 & -24 & -15 & -59 \\
\hline 6 & -62 & -56 & -40 & -22 & -20 & -56 \\
\hline 8 & -58 & -53 & -35 & -23 & -15 & -55 \\
\hline 10 & -50 & -49 & -30 & -15 & -15 & -48 \\
\hline 12.5 & -61 & -58 & -50 & -24 & -10 & -57 \\
\hline 15 & -60 & -57 & -50 & -26 & -30 & -55 \\
\hline 20 & -49 & -50 & -40 & -7 & -15 & -48 \\
\hline 25 & -26 & -28 & -15 & 10 & 0 & -22 \\
\hline 30 & -1 & 0 & 5 & 22 & 30 & 0
\end{tabular}

(1) No data furnished

(2) Below scope limit 
TABLE A4 (Continued)

Scale corrections in thousandths of a degree C. Group IV $\left(-2\right.$ to $\left.30^{\circ} \mathrm{C}\right)$.

Unprotected type thermometers.

Mfg: All Kessler.

NEL recalibration data of Mar 67 include a $0.002^{\circ} \mathrm{C}$ increase due to recalibration of the platinum standard used in the bath.

Kessler Serial No. 602-64

Recalibration

\begin{tabular}{c|cccccc}
$\begin{array}{c}\text { Temperature } \\
{ }^{\circ} \mathrm{C}\end{array}$ & $\begin{array}{c}\text { NOO } \\
\text { Aug 66 }\end{array}$ & $\begin{array}{c}\text { NEL } \\
\text { June } 66\end{array}$ & $\begin{array}{c}\text { WHOI } \\
\text { Mar 66 }\end{array}$ & $\begin{array}{c}\text { SIO } \\
\text { June 66 }\end{array}$ & $\begin{array}{c}\text { KAHL } \\
\text { Feb 67 }\end{array}$ & $\begin{array}{c}\text { NEL } \\
\text { Mar 67 }\end{array}$ \\
\hline-2 & $(3)$ & $(4)$ & $(5)$ & $(1)$ & $(1)$ & $(4)$ \\
\hline 0 & -94 & -75 & -55 & Too low & -58 & -72 \\
\hline 2 & -80 & -73 & -45 & -32 & 60 & -65 \\
\hline 4 & -68 & -59 & -40 & -26 & -15 & -57 \\
\hline 6 & -60 & -52 & -30 & -19 & -20 & -52 \\
\hline 8 & -54 & -50 & -25 & -10 & 0 & -47 \\
\hline 10 & -44 & -45 & -20 & -8 & -10 & -38 \\
\hline 12.5 & -43 & -43 & -25 & -4 & 0 & -37 \\
\hline 15 & -33 & -34 & -15 & 0 & 0 & -31 \\
\hline 20 & -30 & -29 & -20 & 8 & 0 & -27 \\
\hline 25 & -30 & -36 & -20 & -2 & 0 & -28 \\
\hline 30 & -43 & -51 & -35 & -18 & -15 & -45 \\
\hline
\end{tabular}

Kessler Serial No. 604-64

\begin{tabular}{c|cccccc}
-2 & -35 & -35 & -25 & $(1)$ & $(1)$ & -39 \\
\hline 0 & -56 & -50 & -35 & -18 & -20 & -52 \\
\hline 2 & -69 & -64 & -35 & -30 & -20 & -62 \\
\hline 4 & -63 & -56 & -35 & -25 & -15 & -54 \\
\hline 6 & -70 & -64 & -40 & -31 & -30 & -61 \\
\hline 8 & -101 & -97 & -70 & -55 & 50 & -90 \\
\hline 10 & -62 & -62 & -45 & -33 & -30 & -56 \\
\hline 12.5 & -34 & -30 & -15 & 2 & 0 & -25 \\
\hline 15 & -60 & -56 & -45 & -27 & -20 & -53 \\
\hline 20 & -58 & -55 & -50 & -23 & 20 & -52 \\
\hline 25 & -52 & -53 & -45 & -25 & -20 & -47 \\
\hline 30 & -48 & -52 & -40 & -27 & -20 & -44
\end{tabular}

(1) No data furnished

(3) Covered

(4) Obscured

(5) No scale 
TABLE A5. REPEATABILITY OF REVERSING THERMOMETER CALIBRATIONS BY NUWC.

Scale corrections in thousandths of a degree C.

R\&W No. 5193

Temperature

\begin{tabular}{c|c}
${ }^{\circ} \mathrm{C}$ & 6 Jun \\
\hline-2 & -65 \\
\hline 0 & -56 \\
\hline 2 & -5 \\
\hline 4 & -54 \\
\hline 6 & -58 \\
\hline 8 & -58 \\
\hline 10 & -5 \\
\hline 12.5 & -61 \\
\hline 15 & -56
\end{tabular}

Kahl No. 56-1635

\begin{tabular}{c|cccccc}
$\begin{array}{c}\text { Temperature } \\
{ }^{\circ} \mathrm{C}\end{array}$ & $\begin{array}{c}\text { NEL } \\
\text { 6 June } 66\end{array}$ & $\begin{array}{c}\text { NEL } \\
\text { 23 June } 66\end{array}$ & $\begin{array}{c}\text { NEL } \\
\text { 6 June } 66\end{array}$ & $\begin{array}{c}\text { NEL } \\
\text { 23 June } 66\end{array}$ & $\begin{array}{c}\text { NEL } \\
\text { 6 June 66 }\end{array}$ & $\begin{array}{c}\text { NEL } \\
\text { 23 June 66 }\end{array}$ \\
\hline-2 & $(2)$ & $(2)$ & -9 & -10 & 0 & 0 \\
\hline 0 & -28 & -27 & -7 & -9 & 4 & 6 \\
\hline 2 & -22 & -22 & -9 & -10 & 7 & 8 \\
\hline 4 & -1 & -1 & -9 & -12 & 9 & 10 \\
\hline 6 & 0 & 0 & -11 & -12 & & \\
\hline 8 & 0 & 0 & & & & \\
\hline 10 & 0 & 0 & & & &
\end{tabular}

Kahl No. 56-1630

NEL

NEL

NEL

6 June $66 \quad 23$ June 66

$-50$

$-50$

$-50 \quad-1$

$-50 \quad-50$

$-28 \quad-4$

$-24 \quad-52$

$-24 \quad-53$

$-13 \quad-52$

$-52$

$-31$

R\&W No. 10260

R\&W No. 10256

(1) Thermometer malfunction

(2) Off scale 
TABLE A6. COMPARISON OF $V_{0}$ DETERMINATIONS BY THE FOUR LABORATORIES AND THE MANUFACTÜRER.

Data expressed in degrees Centigrade.

\begin{tabular}{cc|ccccc} 
& $\begin{array}{c}\text { Thermometer } \\
\text { Serial No. }\end{array}$ & NOO & NEL & WHOI & SIO & Mfg. \\
\cline { 2 - 7 } & 10254 & 95.9 & 96.3 & 95.9 & 95.9 & 96 \\
Group & 10255 & 101.5 & 101.0 & 101.2 & $(1)$ & 101 \\
I & 10256 & 98.6 & 98.4 & 98.7 & 98.6 & 99 \\
& 10257 & $100.9(2)$ & 100.4 & 101.0 & 100.6 & 101 \\
& 10259 & $(3)$ & 99.2 & 99.4 & $(1)$ & 100 \\
& 10260 & 101.0 & 100.6 & 101.0 & 101.2 & 101 \\
\hline II & 3056 & 105.0 & 104.8 & 105.9 & $(1)$ & 105 \\
& 5193 & 115.1 & 115.8 & 114.4 & 114.5 & 115 \\
& $56-1596$ & 109.1 & 108.6 & 108.5 & 107.9 & 108 \\
III & $56-1630$ & 112.0 & 111.8 & 113.1 & 113.1 & 114 \\
& $56-1635$ & 106.7 & 105.6 & 105.1 & 105.8 & 107 \\
& $64-3989$ & 106.5 & 106.5 & 106.7 & 106.6 & 107.5 \\
\hline \multirow{4}{*}{ IV } & $1459-66$ & 103.2 & 104.7 & 105.5 & 103.0 & 106.1 \\
& $1462-66$ & 105.6 & 106.7 & 106.5 & 106.2 & 108.2 \\
& $1470-66$ & 104.2 & 106.7 & 106.5 & 105.6 & 106.7 \\
& $1475-66$ & 108.6 & 110.2 & 108.0 & 109.5 & 109.7 \\
& $1484-66$ & 106.0 & 106.7 & 107.1 & 106.2 & 108.2 \\
& $1486-66$ & 102.6 & 103.0 & 103.3 & 103.0 & 103.6 \\
\hline \multirow{4}{*}{ Group } & $598-64$ & 121.9 & 122.8 & 123.0 & 122.0 & 122 \\
& $458-64$ & 110.6 & 110.6 & 110.5 & $(1)$ & 120 \\
& $467-64$ & 126.7 & 126.0 & 125.7 & $(1)$ & 128 \\
& $604-64$ & 125.3 & 124.4 & 126.3 & 123.0 & 125 \\
& & 137.9 & 141.2 & 143.0 & $(1)$ & 140 \\
& & 121.9 & $101.1(4)$ & 121.2 & 120.6 & 122 \\
& & & & & &
\end{tabular}

(1) No data fumished

(2) Failed to reproduce on second test

(3) Gas

(4) Thermometer malfunction 
TABLE A7. Q-FACTOR CROSS-CALIBRATION COMPARISON FOR SIX UNPROTECTED REVERSING THERMOMETERS.

Data in ${ }^{\circ} \mathrm{C} /$ hectogram $/ \mathrm{cm}^{2}$.

\begin{tabular}{|c|c|c|c|c|c|c|}
\hline $\begin{array}{c}\text { Thermometer } \\
\text { No. }\end{array}$ & $\begin{array}{c}\text { Test } \\
\text { Pressure } \\
\mathrm{kg} / \mathrm{cm}^{2}\end{array}$ & $\begin{array}{c}\text { NOO } \\
\text { Dec } 66\end{array}$ & $\begin{array}{c}\text { NEL } \\
\text { Nov } 66\end{array}$ & $\begin{array}{c}\text { WHOI } \\
\text { Oct } 66\end{array}$ & $\begin{array}{c}\text { SIO } \\
\text { Dec } 66\end{array}$ & $\begin{array}{l}\text { KAHL } \\
\text { Feb } 67\end{array}$ \\
\hline $458-64$ & $\begin{array}{l}100 \\
200 \\
300 \\
\end{array}$ & $\begin{array}{l}0.0080748 \\
0.0080625 \\
0.0080597 \\
\end{array}$ & $\begin{array}{l}0.008104 \\
0.0080936 \\
0.0080998 \\
\end{array}$ & $\begin{array}{l}0.00811 \\
0.00811 \\
0.00811 \\
\end{array}$ & $\begin{array}{l}0.00812 \\
0.008182 \\
0.008138 \\
\end{array}$ & $\begin{array}{l}0.008149 \\
0.008149 \\
0.008149 \\
\end{array}$ \\
\hline $467-64$ & $\begin{array}{l}100 \\
200 \\
300\end{array}$ & $\begin{array}{l}0.0088453 \\
0.0088212 \\
0.0088256\end{array}$ & $\begin{array}{l}0.008847 \\
0.008860 \\
0.0088654\end{array}$ & $\begin{array}{l}0.00888 \\
0.00888 \\
0.00888 \\
\end{array}$ & $\begin{array}{l}0.00893 \\
0.00909 \\
0.00897\end{array}$ & $\begin{array}{l}0.008933 \\
0.008933 \\
0.008933 \\
\end{array}$ \\
\hline $598-64$ & $\begin{array}{l}100 \\
200 \\
300 \\
\end{array}$ & $\begin{array}{l}0.0090564 \\
0.0090332 \\
0.0090266 \\
\end{array}$ & $\begin{array}{l}0.0090798 \\
0.009072 \\
0.009068 \\
\end{array}$ & $\begin{array}{l}0.00908 \\
0.00908 \\
0.00908 \\
\end{array}$ & $\begin{array}{l}0.00910 \\
0.009118 \\
0.00909 \\
\end{array}$ & $\begin{array}{l}0.0091386 \\
0.0091386 \\
0.0091386 \\
\end{array}$ \\
\hline $601-64$ & $\begin{array}{l}100 \\
200 \\
300 \\
\end{array}$ & $\begin{array}{l}0.0078557 \\
0.0078400 \\
0.0078363 \\
\end{array}$ & $\begin{array}{l}0.0078763 \\
0.0078655 \\
0.0078768 \\
\end{array}$ & $\begin{array}{l}0.00789 \\
0.00789 \\
0.007885 \\
\end{array}$ & $\begin{array}{l}0.00792 \\
0.007955 \\
0.007925 \\
\end{array}$ & $\begin{array}{l}0.007935 \\
0.007935 \\
0.007935 \\
\end{array}$ \\
\hline $602-64$ & $\begin{array}{l}100 \\
200 \\
300 \\
\end{array}$ & $\begin{array}{l}0.0079438 \\
0.0079220 \\
0.0079219 \\
\end{array}$ & $\begin{array}{l}0.007973 \\
0.0079588 \\
0.0079607 \\
\end{array}$ & $\begin{array}{l}0.00797 \\
0.00797 \\
0.00797 \\
\end{array}$ & $\begin{array}{l}0.00800 \\
0.00802 \\
0.008005 \\
\end{array}$ & $\begin{array}{l}0.008028 \\
0.008028 \\
0.008028 \\
\end{array}$ \\
\hline $604-64$ & $\begin{array}{l}100 \\
200 \\
300\end{array}$ & $\begin{array}{l}0.0079288 \\
0.0079280 \\
0.0079163\end{array}$ & $\begin{array}{l}0.0079773 \\
0.0079736 \\
0.0079693\end{array}$ & $\begin{array}{l}0.00797 \\
0.00797 \\
0.00797\end{array}$ & $\begin{array}{l}0.00698 \\
0.00774 \\
0.00796\end{array}$ & $\begin{array}{l}0.007995 \\
0.007995 \\
0.007995\end{array}$ \\
\hline
\end{tabular}


UNCLASSIFIED

Security Classification

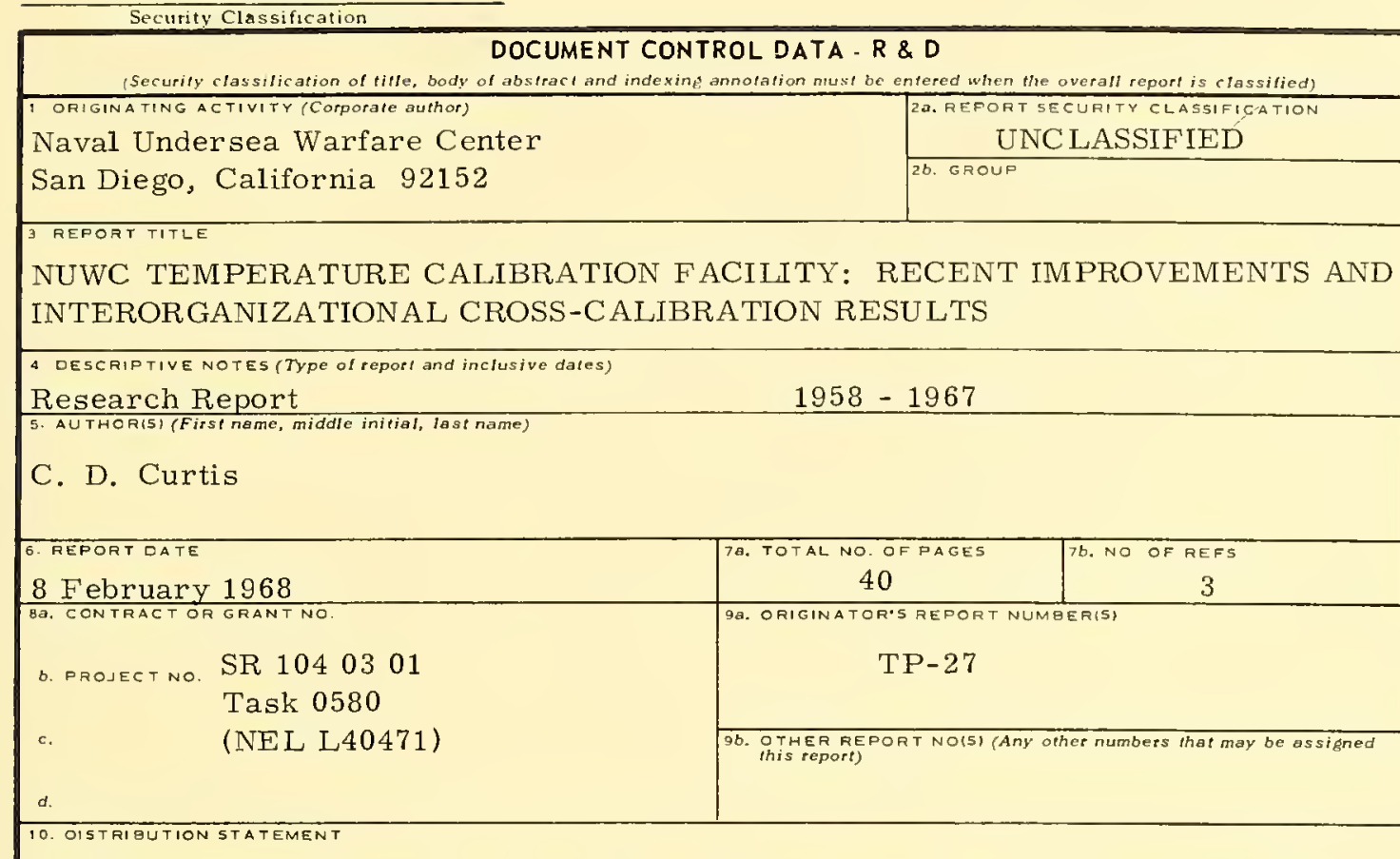

This document has been approved for public release and sale; its distribution is unlimited.

\begin{tabular}{|l|l|}
\hline 11. SUPPLEMENTARY NOTES & $\begin{array}{l}\text { 12. SPONSORING MILITARY ACTIVITY } \\
\text { Naval Ship Systems Command } \\
\text { Department of the Navy }\end{array}$ \\
\hline 13. ABSTRACT
\end{tabular}

Describes the improvements effected during the last ten years, which have made the facility more accurate and versatile. Includes the results of an interorganizational cross-calibration program for reversing thermometers. 
UNC LASSIFIED

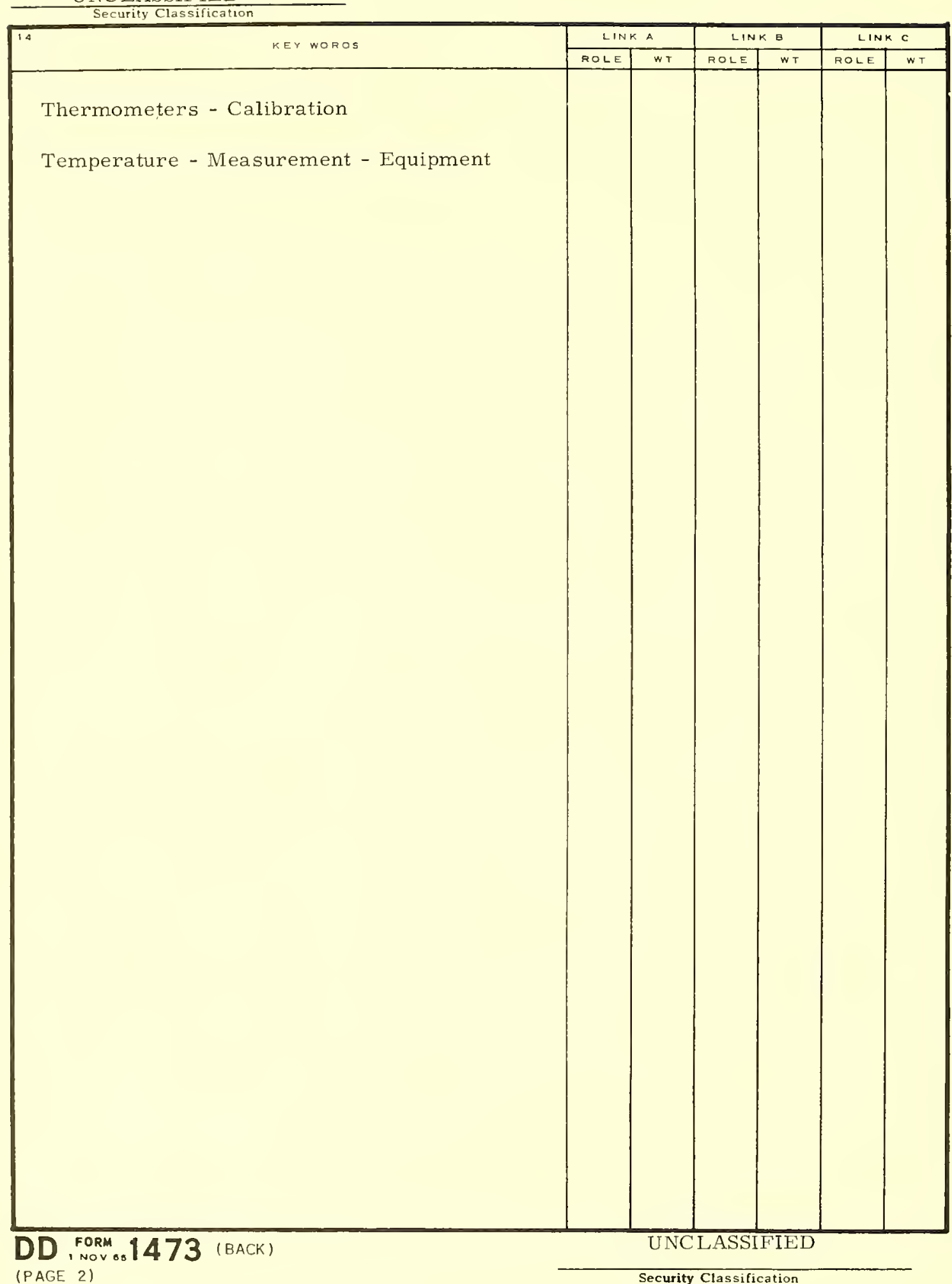






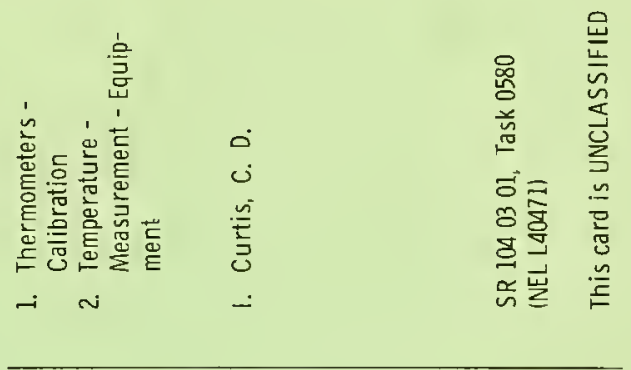

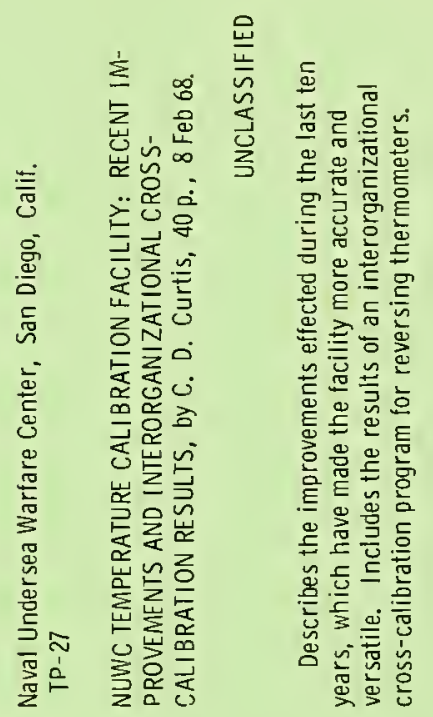


